\title{
Ples na rubu: okolnosti i iskustva položaja mladib u NEET statusu na području Grada Zagreba
}

\author{
Marijana Majdak \\ Danijel Baturina* \\ Gordana Berc ${ }^{* * *}$
}

\author{
https://doi.org/10.31297/hkju.21.1.4 \\ UDK 364.65-057.19-053.6(497.5 Zagreb) \\ 331.526-053.6(497.5 Zagreb) \\ Original scientific paper / izvorni znanstveni rad \\ Received / primljeno: 1.10.2020. \\ Accepted / prihvaćeno: 5. 3.2021.
}

NEET populaciju čine mladi koji nisu uključeni u obrazovanje, prekvalifikaciju ni na tržište rada. Cilj kvalitativnog istraživanja u kojem je sudjelovalo 15 stručnjaka i 25 mladih pripadnika NEET populacije s područja grada Zagreba

* Izv. prof. dr. sc. Marijana Majdak, Studijski centar socijalnog rada, Pravni fakultet Sveučilišta u Zagrebu (Associate professor, Social Work Study Centre, Faculty of Law, University of Zagreb, Croatia, e-mail: marijana.majdak@pravo.hr)

ORCID ID: https://orcid.org/0000-0003-3725-383

** Doc. dr. sc. Danijel Baturina, Studijski centar socijalnog rada, Pravni fakultet Sveučilišta u Zagrebu (Assistant professor, Social Work Study Centre, Faculty of Law, University of Zagreb, Croatia, e-mail: danijel.baturina@pravo.hr)

ORCID ID: https://orcid.org/0000-0002-9063-305

*** Izv. prof. dr. sc. Gordana Berc, Studijski centar socijalnog rada, Pravni fakultet Sveučilišta u Zagrebu (Associate professor, Social Work Study Centre, Faculty of Law, University of Zagreb, Croatia, e-mail: gordana.berc@pravo.hr)

ORCID ID: https://orcid.org/0000-0002-4429-9652 
bio je steći uvid u iskustva pripadnika NEET populacije i stručnjaka koji s njima rade vezano uz rizike koji dovode mlade do NEET statusa te uz njihovu perspektivu za zapošljavanje. Glavni rezultati pokazuju da razloge za nezaposlenost mladi vide u vlastitim neodgovarajućim obrazovnim i stručnim kvalifikacijama s obzirom na potrebe tržišta rada i u nedovoljnoj potpori javnih ustanova u nalaženju posla. Stručnjaci također prepoznaju obrazovni sustav i nepovoljnosti tržišta rada kao čimbenike rizika ulaska mladih u NEET status. Oni izvještavaju o nedostatnim evidencijama NEET populacije, njihovu otežanom dohvatu, teškom izlasku iz NEET statusa te o posljedicama tog statusa za mlade i društvo. Rad daje preporuke za unapređenje politika na lokalnoj i nacionalnoj razini te prakse u radu s NEET populacijom.

Ključne riječi: Grad Zagreb, javne ustanove, NEET populacija, obrazovanje, stručnjaci, tržište rada, zaposlenje

\section{Uvod}

Mlade u dobi od 15 do 29 godina koji nisu zaposleni, nisu u sustavu redovitog obrazovanja ili obrazovanja za odrasle niti su uključeni u neku od mjera osposobljavanja nazivamo NEET populacijom koja je dio ukupne populacije mladih (engl. Not in Employment, Education and Training, NEET) (OECD, 2019). Eurofound (2016) definira NEET populaciju kao izrazito heterogenu skupinu unutar koje je identificirano sedam kategorija mladih: kratkotrajno nezaposleni, dugotrajno nezaposleni, ponovno upisani, nedostupni, oni s obiteljskim obvezama, obeshrabreni radnici i ostale NEET osobe, primjerice oni mladi koji traže zaposlenje, ali ga ne mogu početi zbog vojne službe ili obveza u civilnim službama.

Termin „NEET populacija“ u široj je upotrebi od 2010. kada je u sklopu smjernica za zapošljavanje strategije Europa 2020 Odbor za zapošljavanje (dalje u tekstu: EMCO) Europske komisije postavio prioritet stvaranja preduvjeta za zapošljavanje te populacije s obzirom na njezinu zastupljenost nakon ekonomske krize 2008. (Operativni program - učinkoviti ljudski potencijali, 2014).

Eurofound (2016) naglašava da je NEET populacija iznimno heterogena skupina u većini zemalja, ali je istodobno dijeli na dvije skupine. U prvoj 
su skupini ranjivi NEET mladi kojima prijeti marginalizacija i kojima često nedostaje socijalnih, kulturnih i ljudskih kapitala, a u drugoj su skupini neranjivi NEET mladi koji su bogati kulturnim, socijalnim i ljudskim kapitalom, ali su unatoč tomu NEET i izloženi malom riziku marginalizacije. ${ }^{1}$ Sociodemografski čimbenici ističu da se udio NEET mladih povećava s dobi te da postoji veća vjerojatnost da će mlade žene ući u NEET skupinu u odnosu na mlade muškarce. Vezano uz obrazovna postignuća, najveći dio NEET populacije čine mladi sa završenom srednjom školom (Eurofound, 2016). Koliko prisutnost NEET populacije nije samo osobni nego i društveni problem, pokazuju i podaci iz 2011. prema kojima se procjenjuje da su ekonomski gubici zbog isključenosti mladih s tržišta rada dosegnuli 153 milijarde eura ili 1,2 \% europskog BDP-a (Eurofound, 2012). Podaci Eurostata (2020a) o zastupljenosti NEET populacije na razini Europske unije (28 zemalja) dostupni su od 2010. kada je prosjek udjela mladih u dobi od 15. do 34. godine u NEET statusu bio 16,4 \%, a u Hrvatskoj je iznosio 18,2 \%. U 2012. prosjek udjela te populacije na razini EU-a bilježi porast na $17,1 \%$, a u 2013. na 17,2 \%, dok je u Hrvatskoj 2012. udio iznosio $21,7 \%$, a 2013. godine čak 23,2 \%. Nakon tih zabrinjavajućih podataka mladi u NEET statusu postaju prioritetno pitanje na razini Europske unije, pa se donosi Operativni plan - učinkoviti ljudski potencijali 2014. - 2020. i Plan implementacije Garancije za mlade (PIGzM) 2013. godine (Operativni program - učinkoviti ljudski potencijali 2014. - 2020., 2014). Navedeni dokumenti obvezuju članice EU-a da poduzmu određene mjere i reforme unutar svojih nacionalnih i lokalnih resursa kako bi smanjile udjele NEET populacije u svojim zemljama. Uspostavom Garancije za mlade nastoji se potaknuti uspostava sustava potpore koji će omogućiti da, u skladu s Preporukom o uspostavi Garancije za mlade, sve osobe mlađe od 25 godina dobiju kvalitetnu ponudu za posao, mogućnost nastavka obrazovanja, naukovanje ili pripravništvo u roku od četiri mjeseca od gubitka radnog mjesta ili

1 Daju i nešto detaljniju tipologiju NEET populacije (Eurofound, 2016, str. 30-31): 1) konvencionalno nezaposleni, uobičajeno najveća skupina unutar NEET populacije gdje se dalje mogu razlikovati dugotrajno i kratkotrajno nezaposleni; 2) nedostupni, uglavnom ne mogu prihvatiti posao zbog obiteljskih obveza ili je riječ o osobama s invaliditetom ili drugim poteškoćama; 3) nezainteresirani, odnosno mlade osobe koje ne traže posao ili dodatno obrazovanje te nisu ograničene drugim (obiteljskim) obvezama, ta skupina obuhvaća obeshrabrene radnike, ali isto tako i mlade osobe koje su odabrale rizičniji životni put; 4) osobe u potrazi za boljim mogućnostima, odnosno osobe koje aktivno traže posao ili neku vrstu dodatnog obrazovanja, ali se ne odlučuju prihvatiti neku trenutačnu ponudu jer smatraju da posjeduju vještine koje će im omogućiti dobivanje bolje ponude; 5) dobrovoljni NEETovci - mlade osobe koje putuju ili su na drugi način uključene u razne aktivnosti kao što su umjetnost, glazba ili neformalni oblici učenja. 
prestanka formalnog obrazovanja (Europska komisija, 2020). Kao rezultat provedbe Plana, podaci Eurostata za 2019. pokazuju da se prosjek udjela NEET populacije u 28 zemalja EU-a smanjio na 13,6 \% (odnosno na oko pet milijuna nezaposlenih mladih), što navodi na zaključak da su provedene strategije i aktivnosti ostvarile povoljne rezultate (Eurostat, 2020).

Hrvatska je provedbu politike prema NEET skupini ${ }^{2}$ u okviru Plana Garancije za mlade donijela u prosincu 2013., a dopunila ga je u travnju 2014. ${ }^{3}$ Problem sustavna evidentiranja te populacije u Hrvatskoj sastoji se od izostanka njihova sustavna praćenja i prikupljanja podataka, dok su se neke evidencije uglavnom provodile kroz projekte i programe na lokalnoj razini. Iz tog razloga bilo je potrebno osmisliti sustavan pristup praćenja mladih osoba koje su prekinule školovanje kao i uspostaviti sustav praćenja odjavljivanja iz evidencije HZZ-a kako bi se spriječio ulazak u status NEET koji se (administrativno) može pretvoriti u dugotrajnu nezaposlenost (Bedeniković, 2017b). ${ }^{4}$

Pozitivne rezultate u kontekstu praćenja NEET populacije Hrvatska je 2016. imala u odnosu na pokrivenost te populacije jer je shemom GzM bilo obuhvaćeno više od polovine (54\%) mladih od 15. do 24. godine (prosjek EU-a iznosi 42,5 \%). Ujedno se ukupan broj osoba uključenih u GzM smanjio za $10 \%$ te je praćen status mlade osobe šest mjeseci nakon izlaska iz sheme GzM (tj. izlaska iz evidencije HZZ-a). Navedeni podaci pokazuju vrlo dobar uspjeh provedbe sheme GzM jer je 62,2 \% promatranih mladih osoba i dalje bilo zaposleno ili uključeno u obrazovanje, što je gotovo jednak podatak kao i za 2015. godinu. Najbolje rezultate (iznadprosječne u odnosu na druge članice) Hrvatska je pokazala u praćenju statusa mladih između 12 i 18 mjeseci nakon izlaska iz sheme GzM, kada se većina mladih nalazi u pozitivnoj situaciji (njih $65,6 \%$ nakon 12 te $68,3 \%$ nakon 18 mjeseci) upućujući na to da su ishodi za mlade nakon izlaska iz sheme GzM održivi (Ministarstvo rada i mirovinskog sustava, 2020).

${ }^{2}$ Prvi nacionalni Plan implementacije GzM-a (Youth Guarantee Implementation Plan - YGIP).

${ }^{3}$ Koordinator provedbe GzM-a bilo je Ministarstvo rada i mirovinskog sustava. U skladu s YGIP-om iz 2014. potpora mladima sa statusom NEET koji nisu prijavljeni kao nezaposleni jedva da postoji i obično je provode različite organizacije civilnog društva.

${ }^{4}$ Ministarstvo rada i mirovinskog sustava 2018. provedbom projekta ESF-a „Uspostava sustava praćenja NEET osoba" uspostavio je sustav razmjene podataka između baza obrazovanja te administrativnih podataka o zaposlenima i nezaposlenima. $\mathrm{Na}$ taj se način dobiva jasna slika o nezaposlenim i neaktivnim NEET osobama (tzv. NEET mapping), čime se u konačnici želi utjecati na bolje ciljanje mjera rane intervencije i aktivacije kao i osiguranje brze aktivacije mladih nakon izlaska iz obrazovanja ili ulaska u nezaposlenost (Ministarstvo rada i mirovinskog sustava, 2020). 
Nadalje, u prosincu 2017. EMCO je održao detaljan pregled provedbe Preporuke o uspostavi GzM-a u svim državama članicama koji se provodi svake druge godine. Elementi koji su praćeni odnosili su se na partnerstva pri izradi i provedbi mjera, doseg do NEET osoba, savjetovanje i aktivaciju mladih u NEET statusu te na ocjenu kvalitete ponuda za zapošljavanje, osposobljavanje za samostalan rad, naukovanje i obrazovanje. Hrvatska je za ukupnu implementaciju Preporuke ocijenjena ocjenom četiri od maksimalnih pet bodova, odnosno s visokim stupnjem implementacije GzM-a, s uspostavljenim i dobro razvijenim praksama koje se rutinski provode i integrirane su u cjelokupnu isporuku GzM-a i/ili usluge mladim ljudima. Točnije, zaključeno je da u provedbi Preporuke Hrvatska ispunjava većinu vodećih elemenata, ali nedostaju neki elementi kako bi implementacija bila potpuna (Ministarstvo rada i mirovinskog sustava, 2020). U svibnju 2018. EMCO u izvješću o provedbi GzM-a za Republiku Hrvatsku zaključuje da Hrvatska i dalje ima iznadprosječnu stopu NEET osoba, no postoje jasne naznake oporavka tržišta rada za mlade te je Hrvatska dobro napredovala u provedbi GzM-a. U dokumentu se zaključuje da je Hrvatska predstavila dobro strukturirani PIGzM s jasnim ciljevima, razvila sustav praćenja NEET osoba te priprema kampanju dosega. Fokus je stavljen na individualizirano savjetovanje i sustavan pristup izgradnji partnerstava na lokalnoj razini, pri čemu je potrebno postići jednaku kvalitetu provedbe GzM-a u svim državnim regijama (Ministarstvo rada i mirovinskog sustava, 2020).

Vrijedi spomenuti da su 2018. revidirane mjere HZZ-a u skladu sa Smjernicama za razvoj i provedbu aktivne politike zapošljavanja u Republici Hrvatskoj za razdoblje od 2018. do 2020. godine. Pritom je veći naglasak stavljen na provedbu mjera obrazovanja za potrebe tržišta rada kao i na mjeru pripravništva čijim se osnaživanjem nastoji utjecati na stabilno i kvalitetno uključivanje mladih bez relevantna iskustva na tržište rada (Ministarstvo rada i mirovinskog sustava, 2020).

S obzirom na dosadašnja saznanja o toj problematici i predviđene intervencije usmjerene prema NEET populaciji unutar socijalne politike Republike Hrvatske i nedostatak kvalitativnih istraživanja, u ovom radu bit će prikazani rezultati kvalitativnog istraživanja s mladima u NEET statusu prijavljenima na Zavod za zapošljavanje i stručnjacima iz različitih ustanova i organizacija koji s njima rade. Istraživanje je provedeno na području Grada Zagreba. ${ }^{5}$

5 Istraživanje je provedeno unutar projekta ESF-a. Projekt „Reaktivacija i integracija marginaliziranih mladih - NEET na tržište rada - RIM“ provodio je CERANEO - Centar za razvoj neprofitnih organizacija u partnerstvu s Gradom Zagrebom, Hrvatskim zavodom 
NEET populacija nije do sada bila tema važnijih istraživanja na području Grada Zagreba iako postoje određene analize koje se tiču problematike mladih. Primjerice, istraživalo se ispadanje iz sustava obrazovanja (Berc, Bežovan \& Majdak, 2015), dok je NEET problematika prepoznata i u analizi Socijalne slike Grada Zagreba još 2013. (CERANEO, 2014).

Uz navedena istraživanja i njihove rezultate vezane uz NEET populaciju, teorijska polazišta za istraživanje te teme nalazimo u ekološkim teorijama i teoriji akumulacije nepovoljnosti. Prema ekološkim teorijama (Shaw \& McKay, 2002) društveno funkcioniranje kao i ponašanja pojedinaca rezultat su utjecaja između različitih čimbenika na različitim razinama društva, interakcija pojedinca i okoline, odnosno društvenih sustava (pojedinac - obitelj - škola - susjedstvo - lokalna zajednica politike - sustav). Tako rezultati i ishodi mlade osobe tijekom razvoja i obrazovanja ovise o složenosti cijelog sustava koji ju okružuje te u konačnici dovodi do uspjeha u obrazovanju i pronalasku posla te cjelokupnog ostvarenja na svim razinama i u različitim sustavima. S druge strane, teorija akumulacije nepovoljnosti (Samson \& Laub, 1992), koja je jedna od najnovijih razvojnih teorija, objašnjava kako se poteškoće, problemi i nepovoljnosti jednom nastali (uz međudjelovanje više različitih rizičnih čimbenika) mogu akumulirati te u konačnici dovesti do neuspjeha i nezadovoljstva u životu pojedinca. Na primjer, poteškoće u obrazovnom uspjehu (uzrokovane različitim čimbenicima) mogu dovesti do nezavršavanja škole, problema s vršnjacima, stigmatizacije, druženja s mladima neprihvatljiva ponašanja, nemogućnosti ili lošije mogućnosti u pronalasku posla, loše materijalne situacije, sklonosti nelegalnim poslovima, problema s okolinom i u bliskim odnosima i tako dalje. Na taj se način nepovoljnosti (koje su počele od problema u školovanju) akumuliraju i dovode do začaranog kruga, a pojedinci i društvo u konačnici se moraju nositi s problemima koji nastaju kao posljedica svega. Naravno, sve pod pretpostavkom da se različite okolnosti na različitim razinama funkcioniranja pojedinca poslože tako da dovode do „snježne grude“ ili akumuliranja nepovoljnosti.

Rezultati dobiveni ovim kvalitativnim istraživanjem bit će razmotreni i dovedeni u vezu s navedenim teorijama. U središtu rasprave bit će perspektiva nezaposlenih mladih i stručnog rada s njima vezana uz karakteristike mladih u Hrvatskoj, obilježja obrazovnog sustava i programe i mjere

za zapošljavanje i Institutom za stručno usavršavanje mladih od svibnja do srpnja 2018. te su rezultati objavljeni, u drugom obliku i u ograničenoj nakladi projektne publikacije „Kako odgovoriti na izazove integracije i reaktivacije mladih u NEET statusu“. 
za uključivanje NEET populacije na tržište rada kao i šire mjere socijalne politike koje su im upućene. U zaključku će biti navedene preporuke za unapređivanje prakse $\mathrm{i}$ istraživačkih studija u tom području, ponajviše $u$ vidu prepoznavanja i osvještavanja problema NEET populacije, prevencije i koordinacije djelovanja na otklanjanju socijalnih rizika s kojima se susreću.

\section{Cilj i metodologija istraživanja}

\subsection{Cilj istraživanja}

Glavni cilj istraživanja bio je steći uvid u percepciju pripadnika NEET populacije i stručnjaka koji s njima rade o rizičnim okolnostima koje dovode mlade do NEET statusa te o njihovoj perspektivi na tržištu rada.

Istraživanje s populacijom mladih nezaposlenih imalo je cilj dobiti uvid u njihova iskustva i perspektivu vezano uz vlastitu nezaposlenost, dok je istraživanje sa stručnjacima imalo cilj ispitati ključne specifičnosti NEET populacije iz njihove perspektive te glavne izazove stručnog rada s NEET populacijom.

\subsection{Metodologija istraživanja}

Sudionici istraživanja i način provedbe istraživanja. U ovom istraživanju sudjelovale su dvije skupine sudionika: mladi u NEET statusu i stručnjaci koji s njima rade u različitim institucijama. $\mathrm{S}$ obzirom na specifičnosti uzorka koje se prije svega odnose na njihovu (ne)dostupnost za prikupljanje podataka, korištene su istodobno različite metode prikupljanja podataka i to su fokusne skupine s nezaposlenim mladima te polustrukturirani intervjui sa stručnjacima.

U uzorku NEET populacije sudjelovalo je ukupno 25 mladih osoba (16 žena i 9 muškaraca), od kojih njih 13 ima završenu srednju školu, 7 preddiplomski studij, a 5 ima završen diplomski studij, odnosno magisterij. Oni su u vrijeme provedbe istraživanja bili evidentirani pri Hrvatskom zavodu za zapošljavanje i sudjelovali na radionicama ENTRE-YOU modela koji je provodio Hrvatski zavod za zapošljavanje u suradnji s CERANEO-om. Ukupno je provedeno pet fokusnih skupina u prostorima Centra za mlade Zagreb. 
U uzorku stručnjaka sudjelovalo je ukupno 15 stručnjaka koji su odabrani po kriteriju zaposlenosti u institucijama koje rade s NEET populacijom, a to su stručnjaci iz centara za socijalnu skrb i Hrvatskog zavoda za zapošljavanje te po kriteriju geografske disperzije na području Grada Zagreba, gdje je i provedeno istraživanje. Polustrukturirani intervjui vodili su se prema pripremljenom predlošku koji je nastao nakon prethodno provedene fokusne skupine u kojoj je sudjelovao veći broj stručnjaka radi dobivanja okvirnog uvida u specifičnosti rada s NEET populacijom te radi formuliranja relevantnih tema i pitanja za polustrukturirani intervju.

S obzirom na postavljeni cilj istraživanja koje je provedeno s pripadnicima NEET populacije, definirano je pet istraživačkih pitanja od kojih će u ovom radu biti predstavljena tri, i to su: 1 . kako mladi u NEET statusu objašnjavaju okolnosti koje su dovele do njihove nezaposlenosti, 2. kakva su bila iskustva mladih u NEET statusu tijekom njihova obrazovanja te 3 . kako mladi u NEET statusu vide perspektivu vlastitog zapošljavanja.

Također, u skladu s ciljem istraživanja koje je provedeno sa skupinom stručnjaka, obuhvaćene su četiri teme od kojih će u ovom radu biti prikazane dvije, i to su: 1 . obilježja položaja mladih u riziku da uđu u NEET status te 2. NEET populacija u kontekstu obrazovanja i tržišta rada.

Obrada podataka. Za obradu podataka dobivenih u intervjuima sa stručnjacima korištena je analiza okvira, a za podatke dobivene putem fokusnih skupina s mladima korištena je kvalitativna analiza sadržaja jer se kod stručnjaka pristupilo deduktivno, a kod mladih induktivno. Triangulacija podataka postignuta je integracijom spoznaja i rezultata prethodnih istraživanja o ovoj tematici, a nakon toga dodana je perspektiva stručnjaka i perspektiva mladih. Dakle, u ovom istraživanju korišten je multimetodni kvalitativni pristup s obzirom na to da su tijekom istraživanja istodobno upotrijebljene dvije različite metode za prikupljanje podataka - fokusne skupine i polustrukturirani intervjui. ${ }^{6}$

${ }^{6}$ Takav je pristup prikupljanja i obrade podataka izabran jer su o perspektivi stručnjaka koji rade s pripadnicima NEET populacije prethodno stečene neke spoznaje iz domaćih i stranih istraživanja. Osim toga, prije provedbe pojedinačnih intervjua sa stručnjacima provela se fokusna skupina s većim brojem stručnjaka pri čemu su se razlučile važne i relevantne teme za pripremu polustrukturiranih intervjua. Pritom se u odabiru načina prikupljanja podataka uzela u obzir okolnost da je skupina stručnjaka lakše dostupna i motiviranija za sudjelovanje u istraživanju u odnosu na NEET populaciju, koja je radi nesustavnih evidencija teže dostupna i u načelu manje zainteresirana za sudjelovanje u istraživačkim studijama. Pripadnici NEET populacije, kao što je navedeno, ubrajaju se u teško dostupne uzorke te ih je s obzirom na specifičnosti situacije u kojoj se ti mladi nalaze bilo lakše motivirati na sudjelovanje u fokusnim skupinama nego u pojedinačnim intervjuima zbog skupne dinamike 
Podaci dobiveni u fokusnim skupinama obrađeni su kvalitativnom analizom sadržaja. Riječ je o metodi kojom se nastoji radi zadržavanja autentičnog konteksta i značenja dobivenog sadržaja prikupljena građa prikazati u što izvornijem obliku izražavanja sudionika istraživanja, stoga se ta metoda pokazala metodom izbora za taj uzorak (Kondracki \& Wellman, 2002, prema Hsieh \& Shannon, 2005).

Podaci dobiveni u intervjuima sa stručnjacima obrađeni su postupkom analize okvira (framework analysis), koja se razvila u kontekstu istraživanja javnih (socijalnih, zdravstvenih i dr.) primijenjenih politika s ciljem dobivanja bitnih uvida i preporuka za poboljšanje prakse u kraćem vremenu (Ritchie \& Spencer, 1994). Glavni je cilj analize okvira deskripcija i interpretacija određenih socijalnih pitanja u specifičnom okružju i različitih okolnosti u kojima se određene socijalne teme pojavljuju, pa se u ovom istraživanju za obradu podataka dobivenih intervjuima stručnjaka tematska analiza pokazala kao metoda izbora.

Prikupljena građa u fokusnim skupinama i intervjuima najprije je transkribirana, a zatim organizirana i analizirana. Inicijalni pojmovi koji su se pojavili iz analize empirijske građe apstrahirani su u kategorije koje su u ovom radu prikazane po tematskom okviru za uzorak stručnjaka i po istraživačkim pitanjima za uzorak mladih. U prikazu rezultata pojedini pojmovi ilustrirani izjavama sudionika označeni su šiframa (S1) radi očuvanja anonimnosti sudionika istraživanja. Teme, odnosno pojmovi i kategorije prikazani su u tablicama.

Etička načela za provedbu kvalitativnih istraživanja primijenjena su u ovom istraživanju pod vidom očuvanja anonimnosti i dobrovoljnosti, prava izražavanja vlastitog mišljenja i prava na odustajanje.

\section{Rezultati - rasprava}

\subsection{Perspektiva mladih u NEET statusu}

U vezi s perspektivom mladih o okolnostima koje su dovele do njihove nezaposlenosti analizom odgovora sudionika dobiveno je šest kategorija s pripadajućim pojmovima i izjavama.

te međusobnog poticanja i asociranja istraživačkih sadržaja tijekom provedbe fokusnih skupina. 
Tablica 1. Perspektiva mladih u NEET statusu o okolnostima koje su dovele do njibove nezaposlenosti

\begin{tabular}{|c|c|}
\hline KATEGORIJE & POJMOVI \\
\hline $\begin{array}{l}\text { ograničenja povezana sa } \\
\text { završenim obrazovanjem }\end{array}$ & $\begin{array}{l}\text { neusklađenost obrazovanja i posla } \\
\text { prekvalificiranost } \\
\text { nedostatak radnog iskustva } \\
\text { prekid školovanja } \\
\text { lakša zapošljivost s višim stupnjem obrazovanja } \\
\text { nepoložen vozački ispit kao uvjet zapošljavanja } \\
\text { nedostatak posvećenosti odabranoj struci }\end{array}$ \\
\hline $\begin{array}{l}\text { protuzakoniti načini } \\
\text { zapošljavanja }\end{array}$ & $\begin{array}{l}\text { zapošljavanje preko veze } \\
\text { korupcija } \\
\text { zapošljavanje nestručnih ljudi }\end{array}$ \\
\hline stanje u državi & $\begin{array}{l}\text { nezadovoljstvo vođenjem države } \\
\text { loša ekonomska situacija } \\
\text { nerazvijenost } \\
\text { sporost sustava } \\
\text { nerazumijevanje za mlade ljude } \\
\text { teret na pojedincu } \\
\text { nedostatnost materijalnih resursa u društvu }\end{array}$ \\
\hline individualna obilježja & $\begin{array}{l}\text { osobna odgovornost } \\
\text { nemotiviranost } \\
\text { izgubljenost } \\
\text { izbirljivost pri odabiru posla } \\
\text { nedovoljno prezentacijskih vještina }\end{array}$ \\
\hline $\begin{array}{l}\text { okolnosti povezane s } \\
\text { tržištem rada }\end{array}$ & $\begin{array}{l}\text { stečeno zanimanje za koje ne postoji potražnja na hrvatskom } \\
\text { tržištu rada } \\
\text { nekonkurentnost nekih struka na tržištu rada } \\
\text { neusklađenost obrazovnog sustava s tržištem } \\
\text { stanje na tržištu rada općenito } \\
\text { zapošljavanje studenata } \\
\text { stručno osposobljavanje }\end{array}$ \\
\hline $\begin{array}{l}\text { nedostatna potpora } \\
\text { Hrvatskog zavoda za } \\
\text { zapošljavanje }\end{array}$ & $\begin{array}{l}\text { nuđenje nezadovoljavajućih poslova } \\
\text { želja za radom u odabranoj struci } \\
\text { nezadovoljstvo savjetnicima pri Hrvatskom zavodu za za- } \\
\text { pošljavanje }\end{array}$ \\
\hline
\end{tabular}

Izvor: autori.

Promatrajući prepoznate okolnosti koje su sudionici navodili kao uzroke svoje nezaposlenosti, mogli bismo reći da su iz njihove perspektive same okolnosti u većoj mjeri karakterizirane eksternim nego internim čimbenicima. Mladi, naime, prepoznaju više okolnosti koje nisu pod njihovom mogućnošću utje- 
caja, što može pridonijeti osjećaju beznadnosti jer je znanstveno utvrđeno da eksternost i nalaženje uzroka pretežito u izvanjskim čimbenicima na koje ne možemo utjecati djeluje nemotivirajuće i prepuštajuće sudbini. Okolnosti koje mladi pripadnici NEET populacije vide kao uzroke svoje nezaposlenosti mogli bismo gledati u tri dimenzije. Prva dimenzija povezana je s nekim prepoznatim osobnim obilježjima kao što su njihova ograničenja povezana sa završenim obrazovanjem kao i neka individualna obilježja.

Nezaposleni mladi koji su prijavljeni u evidenciji Hrvatskog zavoda za zapošljavanje smatraju da što se tiče njihova zapošljavanja postoje određena ograničenja povezana sa završenim obrazovanjem, što je bitna okolnost koja je dovela do njihove nezaposlenosti. Ograničenja su povezana s nekoliko bitnih čimbenika, i to su neusklađenost obrazovanja i posla, ${ }^{7}$ zatim nedostatak radnog iskustva, ${ }^{8}$ prekid školovanja, ${ }^{9}$ nedostatak posvećenosti odabranoj struci ${ }^{10}$ te nepoložen vozački ispit kao uvjet zapošljavanja koji poslodavac traži. ${ }^{11}$ Međutim, ograničenja u mogućnosti zapošljavanja, prema percepciji mladih, očituju se i u prekvalificiranosti kao okolnosti koja je povezana s trenutačnom nezaposlenošću s jedne strane ${ }^{12}$ te u percepciji lakše zapošljivosti s višim stupnjem obrazovanja s druge strane. ${ }^{13}$ Mladi prepoznaju i neka individualna obilježja koja doprinose njihovoj nezaposlenosti, a to su osobna odgovornost, nemotiviranost, ${ }^{14}$ izgubljenost ${ }^{15}$ te izbirljivost pri odabiru posla ${ }^{16}$ kao i nedovoljno prezentacijskih vještina. ${ }^{17}$

7 „... ove poslove koje sam imo, njih sam gubio zbog faksa, tj. nije se moglo uskladit ..." (S1)

8 ,... i da imam premalo iskustva."

9 „... prekinuo sam faks.“ (S7)

10 „... nisam imao neke previše ljubavi prema tome.“ (S5)

$11, \ldots$ to što nemam vozački ispit." (S20)

12 ,... većini slučajeva mi kažu da sam prekvalificirana, da imam previše i onda ne mogu dobiti ni onaj najosnovniji posao." (S23)

13 „... ali jednostavno nas se ograničava u tome $\mathrm{i} u$ jednom trenutku nas se omalovažava zato što smo mi sad prvostupnici trenutno ..." (S8)

14 „Ja sam isto kriva što ne tražim baš svaki poso, al tražim ono aktivno, ali onda odustanem jer onda više odustanem jer onda više vidim da nema." (S9)

15 „Nedostatak fokusa u životu, definiranih ciljeva, prelako zapadam u apatiju i malodušnost." (S6)

16 „... jesam malo izbirljiva što se tiče poslova tako da pokušavam naći posao baš u kulturi, da bude povezano s ovim što sam studirala ..." (S21)

17 „Na razgovorima za posao sam zaključila da mi je problem samopouzdanje. I onda, nisam svjesna toga da tiho pričam i onda su mi rekli bili da se stekne krivi dojam o mojim sposobnostima ..." (S22) 
Druga dimenzija u kojoj mladi vide uzroke svoje nezaposlenosti okolnosti su društva, odnosno okoline. Unutar društvenih utjecaja mladi prepoznaju protuzakonite načine zapošljavanja (zapošljavanje preko veze, ${ }^{18}$ korupcija, ${ }^{19}$ zapošljavanje nestručnih $\operatorname{ljudi}^{20}$ ) te stanje u državi (nezadovoljstvo vođenjem države, ${ }^{21}$ loša ekonomska situacija u društvu ${ }^{22}$, zatim nerazvijenost ${ }^{23}$ i sporost sustava ${ }^{24}$ kao i nerazumijevanje za mlade ljude..$^{25}$ Mladi osjećaju kao da je teret na pojedincu ${ }^{26}$ te da postoji nedostatnost materijalnih resursa u društvu. ${ }^{27} \mathrm{Uz}$ navedeno, prepoznate su i okolnosti povezane s tržištem rada, na primjer, stečeno zanimanje za koje ne postoji potražnja na hrvatskom tržištu rada ${ }^{28}$ zatim nekonkurentnost nekih struka na tržištu rada, ${ }^{29}$ neusklađenost obrazovnog sustava s tržištem rada, ${ }^{30}$ stanje na tržištu rada općenito. ${ }^{31}$ Mladi također misle da je neisplativo zapošljavanje u redovitom statusu, što potkrepljuju kroz kodove o zapošljavanju studenata ${ }^{32}$ te kroz stručno osposobljavanje. ${ }^{33}$

18 ,... neki poslodavci koji stave oglase samo reda radi, a onda mislim nije tajna da zaposle nekog svog preko veze." (S1)

19 „... Ili traže mito velikih cifri." (S8)

20 ,... to što ima puno ljudi i sa lažnim diplomama koji dobe posao ..." (S8)

21 „To sve kreće od vlade. Previše uzimaju. Jednostavno prevelike stvari uzimaju." (S1)

22 „... bi trebala biti situacija ekonomska povoljnija u državi.“ (S20)

23 „... iz nekog razloga čitava ta administracija na strani države je zastarjela." (S25)

24 „Puno poslodavaca je reklo da oni zapravo čekaju da im država odobri da oni mogu uzeti nekoga. I tu je isto dugi period čekanja." (S23)

25 „... mladim ljudima ne daju priliku ..." (S8)

26 „Ne možemo mi sve sami. Shvaćaš. Onda uopće ne trebamo biti ni prijavljeni, ionako si sve sami tražimo." (S8)

27 „Znači novac strašno puno igra. I isto tako je problem današnjeg društva kol'ko ljude se ide obrazovat, stavljaju svoju imovinu pod hipoteku, razni ..." (S8)

28 „... jednostavno struka koju sam završio nije općenito zapošljiva ..." (S6)

29 „Pa evo, s moje strane, što se tiče završenog magistra ... tehnologije, s jednim problemom kaj nema na tržištu rada, ne postoji ta, to zanimanje nije konkurentno ..." (S15)

30 „I danas svatko završi faks i tu imamo opet čep. Imamo toliko visokoobrazovanih. Ljudi uglavnom idu studirati zato što mogu, dok je vani to veliki, veliki luksuz. I zato možda vani ima više prilika za posao jer visokoobrazovanih nema toliko." (S23)

31 „... vjerojatno kombinacija, znači stvari, trenutne situacije na tržištu rada i mojih interesa ..." (S12)

32 „I studente što ne trebaju plaćat zdravstveno ništa." (S9)

33 ,... problem ovo stručno osposobljavanje jer oni drže nekog godinu dana i onda nakon nekog vremena opet uzmu nekog na godinu dana i uvijek imaju besplatnog radnika." (S8) 
Treća dimenzija mogla bi se opisati kao očekivana potpora mladima koju nisu dobili. Mladi su, naime, istaknuli nedostatnu potporu Hrvatskog zavoda za zapošljavanje, što je vidljivo u nezadovoljstvu savjetnicima pri Hrvatskom zavodu za zapošljavanje ${ }^{34}$ te u nuđenju nezadovoljavajućih poslova za mlade od Zavoda za zapošljavanje ${ }^{35}$ dok oni žele raditi u struci. ${ }^{36}$ Drugo istraživačko pitanje bilo je usmjereno na iskustva mladih u NEET statusu tijekom obrazovanja, pri čemu su njihovim odgovorima dobivene tri kategorije s pripadajućim pojmovima.

Tablica 2. Iskustva mladib osoba u NEET statusu tijekom njibova obrazovanja

\begin{tabular}{|l|l|}
\hline KATEGORIJE & \multicolumn{1}{c|}{ POJMOVI } \\
\hline $\begin{array}{l}\text { zadovoljena } \\
\text { očekivanja tijekom } \\
\text { obrazovanja }\end{array}$ & $\begin{array}{l}\text { formalno obrazovanje kao temelj za daljnji napredak } \\
\text { zadovoljstvo odabirom obrazovanja } \\
\text { zanimljivo gradivo } \\
\text { zalaganja profesora } \\
\text { pravovaljano informiranje o mogućnostima nakon obrazovanja } \\
\text { pozitivna iskustva tijekom praktične nastave }\end{array}$ \\
\hline \multirow{2}{*}{$\begin{array}{l}\text { nezadovoljstvo profesorima } \\
\text { obrazovnim } \\
\text { sustavom u cjelini }\end{array}$} & $\begin{array}{l}\text { neskorisnost studiranja } \\
\text { nedovoljno informiranja o stanju na tržištu rada } \\
\text { nedogramima informiranja i usmjeravanja o dostupnim obrazovnim } \\
\text { nepoštivanje različitosti u sposobnostima i interesima } \\
\text { premalo praktične nastave } \\
\text { loša iskustva tijekom praktične nastave } \\
\text { nerelevantnosti nastavnog gradiva } \\
\text { opširnosti nastavnog gradiva } \\
\text { neuskladenosti obrazovnog gradiva s potrebama na tržištu rada } \\
\text { manjak znanja iz opće kulture } \\
\text { fokus na ocjenama }\end{array}$ \\
\hline $\begin{array}{l}\text { zaostao sustav } \\
\text { obrazovanja }\end{array}$ & $\begin{array}{l}\text { potreba za većim materijalnim ulaganjima } \\
\text { zastarjelost sustava obrazovanja - fokus na teoriji } \\
\text { nepotizam }\end{array}$ \\
\hline
\end{tabular}

Izvor: autori.

34 „Tek tolko da nas se riješe i ispune svoje ..." (S8)

35 „Htio bi se samo nadovezati na savjetnike pri zapošljavanju.“ (S2) „... ja osobno imam osjećaj kao da izdajem sebe i svoju struku ako se zaposlim negdje drugdje ..." (S23)

36 ,... ja osobno imam osjećaj kao da izdajem sebe i svoju struku ako se zaposlim negdje drugdje." (S23) 
Sveukupno gledajući, mladi su tijekom nastave u okviru svog obrazovanja imali i pozitivna i negativna iskustva, no može se reći da su više prepoznali $i$ isticali negativna. Mogli bismo istaknuti da su nedostaci obrazovanja koje su mladi navodili vrlo ozbiljne prirode te da bi njihovo otklanjanje zahtijevalo sveobuhvatne promjene u obrazovnom sustavu.

Od zadovoljenih očekivanja tijekom obrazovanja mladi uglavnom prepoznaju pozitivne utjecaje profesora, nastavnog gradiva i praktične nastave. Tako navode formalno obrazovanje kao temelj za daljnji napredak, ${ }^{37}$ zadovoljstvo odabirom obrazovanja, ${ }^{38}$ zanimljivo gradivo, ${ }^{39}$ zalaganja profeso$\mathrm{ra}^{40}$ i pravovaljano informiranje o mogućnostima nakon obrazovanja ${ }^{41}$ te pozitivna iskustva tijekom praktične nastave. ${ }^{42}$

Kad je u pitanju nezadovoljstvo obrazovnim sustavom u cjelini, odgovore mladih možemo promatrati ponovno u nekoliko dimenzija. Prva dimenzija povezana je s nezadovoljstvom nastavom i profesorima, pa tako mladi ističu nezadovoljstvo profesorima, ${ }^{43}$ nerelevantnosti nastavnog gradiva ${ }^{44}$ kao i opširnost nastavnog gradiva, ${ }^{45}$ beskorisnost studiranja, ${ }^{46}$ manjak znanja iz opće kulture ${ }^{47}$ te da su kod profesora zapazili da je fokus na ocjenama. ${ }^{48}$

Druga dimenzija odnosi se na praktičnu nastavu unutar obrazovnog procesa. Mladi navode iskustvo neusklađenosti izvođenja praktične nastave,

37 „... baš zato sam ja upisala stručni studij jer daju i teoriju i praktični dio i onda steknete onda to neko znanje koje vam je kostur ..." (S8)

38 „Faks je bio fenomenalan, pet godina najljepših, najboljih. Od profesora, od kolega, od terena. Znači nisam požalila. Zbilja sam obožavala to, još uvijek obožavam." (S23)

39 ,... s obzirom da je to studij hrvatske kulture, tu ima svega i svačega. To je od jezika, povijesti, kulture, običaja, tu je sve moguće i to mi je bilo jako zanimljivo." (S21)

40 „... to nas je učio profesor da mi primijenimo teoriju u svoj praktični tako." (S4)

41 „... u stručnom studiju nas su i pripremili za tržište rada ..." (S8)

$42, \ldots$ mi smo imali jedan dan normalne škole i tjedan dana prakse naprema i mi smo imali razliku i u tom praksi." (S5)

43 „... ljudi koji su naučili tako radit' i tog se drže. I onda će tamo bit' do penzije.“

44 „... uči se hrpa stvari koje ja mislim da nama ni ne trebaju." (S22)

45 „... dovoljno je obrazovanje kao širok spektar znanja, ali za nešto specifično ne.“

$46, \ldots$ ispada da sam ja uzalud trošio tri godine na faksu ..." (S1)

47 „Fali više onog etičkog ponašanja. Naći više uvesti u škole etike.“ (S8)

48 „... u srednjoj školi, vrlo je bitno naučit, dobit' ocjenu i na faksu isto tako ..." (S14) 
što je vidljivo u navedenim iskustvima s premalo praktične nastave ${ }^{49}$ te $u$ lošim iskustvima tijekom praktične nastave. ${ }^{50}$

Treća dimenzija govori o nedostatku informiranosti o obrazovnim programima i nedostatku povezanosti između obrazovnog sustava i planiranja na tržištu rada te je kod izjava sudionika prepoznata u neusklađenosti obrazovnog gradiva s potrebama na tržištu rada, ${ }^{51}$ nedovoljnom informiranju o stanju na tržištu rada, ${ }^{52}$ nedovoljnom informiranju i usmjeravanju o dostupnim obrazovnim programima. ${ }^{53}$

Četvrta dimenzija odnosi se na nedovoljnu osjetljivost i prilagođenost obrazovnog sustava interesima i sposobnostima mladih. Mladi su primijetili nepoštivanje različitosti u sposobnostima i interesima. ${ }^{54} \mathrm{Da}$ je sustav obrazovanja zaostao, mladi prepoznaju u potrebi za većim materijalnim ulaganjima ${ }^{55}$ u sustav, u zastarjelosti sustava obrazovanja ${ }^{56}$ te $u$ fokusu na teoriji $^{57}$ i u prisutnosti nepotizma. ${ }^{58}$

Nakon analize rezultata vezanih uz perspektivu vlastite zapošljivosti mladih u NEET statusu dobivene su četiri kategorije s pripadajućim izjavama.

49 „... nakon škole uopće nije bilo praktične nastave." (S3)

$50, \ldots$ ne da jedna firma nekoga pripremi za nešto bolje, a drugima daju ono samo nekakve pomoćne poslove jer svi trebaju imat isto inače postoji plan i program, ali se ne pridržavaju svi toga i to je isto problem." (S8)

51 „... onda uočimo velike probleme možda i razlike teorijskog i praktičnog djelovanja." (S15)

52 ,... ako ću gledati u cjelini taj svoj cijeli studij, aaa studij kao na razini samog studija kao takvog nas uopće ne pripremaju na realno stanje stvari ovdje u Hrvatskoj." (S17)

$53, \ldots$ tijekom srednjoškolskog obrazovanja sam imao nekakvu određenu sliku o tome što ću zapravo raditi ..." (S12)

54 „Na primjer ja nisam, ne znam, u osnovnoj školi previše volio povijest il kemiju il ne znam biologiju u osmom razredu i onda ono malo olakšate znate. Ne želite sad ono a moraš moraš moraš. Znači to je glup način. Tako forsirat ljude.“ (S5), „... mislim da bi nas trebali naučit pronać naše snage i usmjerit nas. Ne bi nas trebali sve gledat jednako." (S10)

55 „Malo to bolje rasporedit i ulagat, sad vidim, da sve više ide na strojeve, kompjuterizacija i tako." (S9)

56 „Jer sam ja tek u srednjoj to vidio, to možda za kasniji sustav koji jednostavno treba sustav možda promijenit', znači ubrzat ..." (S12)

57 ,... ja se možda previše fokusiram na nekakve teorije, naći imao sam ja više mogućnosti možda više ići u neki istraživački rad, metodologije i to, al nije me to tolko zanimalo." (S6)

58 „... školi je bilo to, ne znam, fokusirano dosta na nepotizam ..." (S5) 
Tablica 3. Perspektiva vlastite zapošliivosti mladib u NEET statusu

\begin{tabular}{|l|l|}
\hline KATEGORIJE & \multicolumn{1}{c|}{ POJMOVI } \\
\hline $\begin{array}{l}\text { odabrano } \\
\text { zanimanje }\end{array}$ & $\begin{array}{l}\text { je li zanimanje za koje su se obrazovali traženo } \\
\text { zanimanje za kojim nema potrebe na tržištu rada }\end{array}$ \\
\hline $\begin{array}{l}\text { optimistična } \\
\text { perspektiva } \\
\text { pronalaska posla u }\end{array}$ & $\begin{array}{l}\text { velika mogućnost za pronalazak posla } \\
\text { mogućnost samozapošljavanja } \\
\text { mogućnost razvitka } \\
\text { poticaj za osobni razvoj } \\
\text { veća mogućnost zapošljavanja u određenim dijelovima Hrvatske } \\
\text { vjera u promjenu }\end{array}$ \\
\hline $\begin{array}{l}\text { mogućnost } \\
\text { zapošljavanja } \\
\text { posredovanjem } \\
\text { drugih ljudi }\end{array}$ & $\begin{array}{l}\text { zapošljavanje preko veze } \\
\text { važnost poznanstva }\end{array}$ \\
\hline $\begin{array}{l}\text { male mogućnosti } \\
\text { pronalaska posla u } \\
\text { Hrvatskoj }\end{array}$ & $\begin{array}{l}\text { zaposlenje se dugo čeka } \\
\text { nedostatak prigoda za iskazivanje } \\
\text { borba za pronalazak posla } \\
\text { nekorektno ponašanje poslodavaca nakon razgovora za posao } \\
\text { strah od neisplaćivanja plaće } \\
\text { nedostatak rješenja problema nezaposlenosti na razini države } \\
\text { razmišljanje o mogućnosti preseljenja izvan Hrvatske } \\
\text { ponude za neadekvatne poslove } \\
\text { ponude za posao izvan struke }\end{array}$ \\
\hline
\end{tabular}

Izvor: autori.

Vezano uz perspektivu oko vlastite zapošljivosti, mlade osobe imaju dvojaka razmišljanja, pa tako jedan dio mladih smatra da su mogućnosti njihova zapošljavanja u Hrvatskoj male, a dio vidi solidne mogućnosti zapošljavanja u Hrvatskoj i nada se pronalasku posla. Ujedno neki mladi misle da pronalazak posla ovisi o njihovu odabranom zanimanju koje je i razlog za ograničenje u zapošljavanju, ali i da dobivanje posla ovisi o poznanstvu utjecajne osobe koja može posredovati u zapošljavanju osobe.

Mladi koji misle da pronalazak posla ovisi o odabranom zanimanju navodili su da je važno je li zanimanje za koje su se obrazovali traženo ${ }^{59}$ ili je riječ o zanimanju za kojim nema potrebe na tržištu. ${ }^{60}$

59 „... ja kao kuhar traženo je to zanimanje i svi baš to ono traže. Ja mislim da ću se ja dobro snaći u Hrvatskoj." (S4)

60 „... tak da ne mogu reći da nisam, da sam mislio da ću odma neći posao u struci nakon završetka fakulteta." (S6) 
Optimistična perspektiva pronalaska posla u Hrvatskoj vidljiva je u mišljenjima mladih da postoji velika mogućnost za pronalazak posla ${ }^{61}$ i mogućnost samozapošljavanja. ${ }^{62}$ Neki mladi iskazuju povjerenje u razvoj sustava zapošljavanja u Hrvatskoj kroz mogućnost razvitka, ${ }^{63}$ poticaj za osobni razvoj ${ }^{64} \mathrm{i}$ vjeru u promjenu. ${ }^{65}$ Dio mladih smatra da je perspektiva pronalaska posla povoljnija u nekim dijelovima Hrvatske, pri čemu ističu mogućnost zapošljavanja u Istri ${ }^{66} \mathrm{i}$ mogućnost zapošljavanja u Zagrebu. ${ }^{67}$ Mladi također ističu da se perspektiva zapošljavanja povećava posredovanjem drugih ljudi, što je vidljivo kroz kodove zapošljavanje preko veze ${ }^{68} \mathrm{i}$ važnost poznanstva ${ }^{69}$ U rezultatima je vidljiva i pesimistična perspektiva mladih o njihovu zapošljavanju prema kojoj je teško pronaći posao u Hrvatskoj uz naglasak na to da su mogućnosti zaposlenja u Hrvatskoj male jer se zaposlenje dugo čeka, ${ }^{70}$ jer postoji nedostatak prigoda za iskazivanje, ${ }^{71}$ jer je prisutna borba za pronalazak posla, ${ }^{72}$ zatim nekorektno ponašanje poslodavaca nakon razgovora za posao, ${ }^{73}$ strah od neisplaćivanja plaće $\mathrm{e}^{74}$

61 „Ne čekam poso. Ja si nađem poso. Tako da zapravo ja nikad nisam imala problema s nalaskom posla." (S11)

$62, \ldots$ imam ideju se samozaposliti putem nekakvih... samozaposliti i onda kao nekakav freelancer surađivati ostalim tvrtkama ..." (S17)

63 „... mislim da za ustvari ima punog praznog prostora za nekakvi rast ..." (S16)

64 „... jer teren takav kakav je, nas tjera na svakodnevno učenje konstantno.“ (S17)

65 „Pa ne znam, ja sam uvijek nekako bila i optimist.“ (S12)

66 „... u Istri za vrijeme sezone ono traže stalno.“ (S11)

67 „... jel' kako gledam, posao gledam i pod drugim gradovima, u Zagrebu ima najviše prilika." (S18)

68 „... hoćeš imati iskustvo i točno obrazovanje koje traže i sve sve sve sve i onda ono što kaže kolega uzmu nekog svog koji nema veze s tim." (S2)

69 „Meni su od velike pomoći prijatelji koji su već zaposleni ..." (S18)

70 „Mislim da nekako krivo uvjerenje postoji kao može se naći posao na svakom kutku ..." $(\mathrm{S} 2)$

71 ,... mi koji tražimo poso i sve koji imamo neka znanja koja bi mogli pokazati i sve samo da dobijemo priliku nama je to onemogućeno." (S8)

72 „Ne da se zapravo mi borimo za posao, nego da se više poslodavci bore za nas. Ajmo tako reći. Da zapravo oni nas zovu. To bi bila neka bolja. Al ko zna kad će to doći." (S7)

73 „... u vezi poslodavaca. Znači kad se njima znamo javiti na natječaj za posao neki uopće ne pošalju povratni odgovor (...) Ili uopće ne obavijestiti što nije u redu od njihove strane.“ (S8); „... u većini slučajeva ideš uzaludno. Odeš tamo, ponadaš se i onda mjeseci prođu. Par puta sam znala dobiti odgovor nakon 3-4 mjeseca." (S23)

74 „A mi imamo samo u državnim firmama da će ljudi biti plaćeni, to je užasno mali spektar što je sigurno plaćeno, mislim da se danas jako puno ljudi boji upravo zato i biti možda i zaposleno ..." (S16) 
te je prisutan stav kod mladih da prevladava nedostatak rješenja problema nezaposlenosti na razini države. ${ }^{75}$ Nadalje, mladi ističu da je moguće zaposliti se na neželjenim poslovima, i to je vidljivo kroz kodove ponude za neadekvatne poslove ${ }^{76}$ i ponude za posao izvan struke. ${ }^{77}$ Neki mladi ističu da perspektivu pronalaska posla vide i izvan Hrvatske, odnosno da razmišljaju o mogućnosti preseljenja izvan Hrvatske. ${ }^{78}$

\subsection{Perspektiva stručnjaka koji rade s mladima u NEET statusu}

Istraživanjem smo ostvarili i uvid u perspektivu stručnjaka vezanu uz mogućnosti mladih u kontekstu obrazovanja i tržišta rada kao i uz njihove karakteristike, pa u nastavku slijedi prikaz dobivenih rezultata za tu skupinu sudionika istraživanja.

Tablica 4. NEET u kontekstu obrazovanja i tržišta rada

\begin{tabular}{|l|l|}
\hline TEME & \multicolumn{1}{c|}{ POJMOVI } \\
\hline $\begin{array}{l}\text { obrazovanje kao faktor } \\
\text { rizika za postajanje } \\
\text { NEET-ovcem }\end{array}$ & $\begin{array}{l}\text { zastarjelost i neadekvatnost obrazovnog sustava } \\
\text { manjak usmjerenosti na praksu } \\
\text { neusklađenost s potrebama tržišta rada }\end{array}$ \\
\hline $\begin{array}{l}\text { otežavajući aspekti } \\
\text { NEET-ovaca za integraciju } \\
\text { na tržište rada }\end{array}$ & $\begin{array}{l}\text { manjak informiranosti o tržištu rada } \\
\text { neutemeljena očekivanja za prve poslove } \\
\text { nedostatak iskustva }\end{array}$ \\
\cline { 2 - 2 } & $\begin{array}{l}\text { stigmatizacija odredenih skupina NEET-ovaca } \\
\text { nerealna očekivanja poslodavaca od NEET-ovaca } \\
\text { nepovoljne prakse poslodavaca }\end{array}$ \\
\hline nepovoljna obilježja tržišta \\
rada
\end{tabular}

Izvor: autori.

75 „Ne postoji neka strategija ...“ (S6)

76 „... al' ipak sam četiri mjeseca na burzi, pa bolje išta nego ništa, ali kao ipak da me toliko gazi, ali to je gaze vas ..." (S13); ,... to su nekakvi poslovi, ja volim progooglat direktore i takve stvari, opću situaciju firme. To su ne znam direktori koji imaju par firmi i ona mi to (...) Možete samo pretpostavit kakvo im je poslovanje." (S19)

77 „Znači ne uopće da se mi razvijamo u željenoj struci, nego ovak nekakve znate pomoćne poslove." (S8); ,... dobivam nekakve oglase koji jednostavno nisu u mojoj struci kao na primjer spasioc tak' da to ..." (S15)

78 „Volim Hrvatsku jako i prekrasna mi je, al ak vidim da u nekakvom poslovnom svijetu i tom putu ne uspijem, nemam problema s tim da odem.“ (S2); „Možda bi čak i htjela otići izvan Hrvatske." (S3) 
Kontekst sustava obrazovanja i tržišta rada kao glavnih odrednica konačna izlaska mladih iz NEET statusa bila je istraživačka tema unutar koje se željelo prepoznati ograničenja i mogućnosti s kojima se NEET populacija susreće u obrazovanju i na tržištu rada.

Može se primijetiti da stručnjaci, kao i mladi, što se tiče čimbenika vezanih uz postajanje NEET populacijom stavljaju naglasak u većoj mjeri na vanjske čimbenike (obrazovanje kao proces i stanje na tržištu rada), a samo manjim dijelom na čimbenike vezane uz same mlade i njihova obilježja.

Razmatrajući navedenu temu, stručnjaci prepoznaju obrazovanje kao faktor rizika za postajanje NEET-ovcem te navode zastarjelost obrazovnih programa i načina obrazovanja u kojem se mladima ne nude kritičke vještine i znanja. Obrazovni sustav stručnjaci procjenjuju tromim i nefleksibilnim. ${ }^{79}$ Posebno je bitan manjak usmjerenosti na praksu koja bi mnogim NEET-ovcima, posebice onima sa strukovnim zanimanjima, dala veće izglede za pronalazak posla. ${ }^{80}$ Velika boljka, prema mišljenjima stručnjaka, tiče se neusklađenosti obrazovanja i potreba tržišta rada. ${ }^{81} \mathrm{U}$ vezi s tim oni vide brojne mlade osobe koje su obrazovane za zanimanja koja nisu tražena na tržištu i jasno postojanje prevelikih upisnih kvota za pojedina zanimanja, što u konačnici dovodi do otežane zapošljivosti tih mladih.

Stručnjaci upozoravaju na brojne poteškoće za NEET populaciju koje proizlaze iz karakteristika tržišta rada te prepoznaju nepovoljna obilježja tržišta rada. Katkad postoji stigmatizacija NEET-ovaca s obzirom na njihovu mladost i neiskustvo, što se češće javlja za određene skupine, primjerice Rome koji su obilježeni negativnim stereotipima ili za osobe koje su počinile kaznena djela zbog njihove prošlosti. ${ }^{82}$ Isto tako, stručnjaci u

79 „... selekcija napraviti to gradivo, dati im, jer ustvari vi njih možete motivirati da oni uče više, da žele naučiti. Naša djeca ne uče zato da bi željeli, da bi znali. Oni nauče, oni uče, pa ja mislim 80 \% njih za ocjenu, nema veze koja je. Neko uči samo da dobije 2, neko uči samo da prođe srednju školu, neko uči za 5 jer mu je to važno, ali mali broj djece uči zato da bi naučilo nešto." (STR3)

80 „Da, još imaju, ali čini mi se da bi trebali, oni dosta te teorije nauče, do tog praktičnog nekakvoga dijela masa njih zna doći i reći ja nisam ni znao kud se upisujem. Znate..., tak da mi se čini nekako da bi trebalo taj praktični da ide od početka." (STR3)

81 „To su neki tehnički problemi jer se ne možemo spojiti s trenutnim tržištem rada, a da ne pričam da obrazujemo ljude za nešto što nema posla i da nikako ne potičemo strukovno." (STR8)

82 „... upravo za one koji su se pojavili kao počinitelji kaznenih djela, najčešće su to bile ili krađe ili neke tjelesne ozljede pa uglavnom onda s njima zapravo radim upravo na tome da ih nekako integriram u društvo i pokušam im pomoć zapravo pri zapošljavanju. Iako 
jednom dijelu vide i nerealna očekivanja poslodavaca u smislu zahtjeva koji su mnogo iznad onoga što se može očekivati za osobu koja tek ulazi na tržište rada ili ima kratkotrajno iskustvo na tržištu rada. ${ }^{83}$ Osim toga, stručnjaci navode i postojanje nepovoljnih praksa poslodavaca koje se tiču rada na crno ili nepoštivanja ugovora u vezi s plaćom, radnim vremenom ili uvjetima rada koje utječu na činjenicu da mladi brzo odustaju od takvih poslova ili se osjećaju izrabljivanima.

Stručnjaci prepoznaju da postoje otežavajući aspekti NEET-ovaca za integraciju na tržište rada, pri čemu uočavaju da mladi često nisu informirani o tržištu rada ${ }^{84}$ Oni nemaju jasan dojam gdje bi se i kako mogli zaposliti i koji ih radni uvjeti čekaju. To im oblikuje i očekivanja, pri čemu onda teško prihvaćaju prve poslove koji su slabo plaćeni ili prema njihovoj percepciji nemaju dobre uvjete rada. Stručnjaci iskazuju da mladi očekuju bolja zaposlenja od realnosti svoga obrazovnog statusa i radnog iskustva. ${ }^{85}$ Iskustvo se pokazuje kao ključan aspekt i kriterij zapošljavanja. Stručnjaci prepoznaju boljku obrazovnog sustava koji ne daje dovoljno praktične nastave, no s druge se strane pokazuje da poslodavci očekuju određeno radno iskustvo kod tražitelja posla te preferiraju radnike $\mathrm{s}$ iskustvom rada. ${ }^{86}$ Što se tiče nekih drugih kanala jačanja kapaciteta NEET populacije poput volontiranja, stručnjaci ne vide da se mladi koji pripadaju NEET populaciji uključuju u njega ili pokazuju motivaciju za uključivanje u takvu vrstu radne aktivnosti, što s obzirom na njihov ranjiv položaj ne iznenađuje.

se ja tu nalazim u poziciji gdje sam jako, jako nemoćna jer je malo poslodavaca koji bi, ne samo mladu osobu, nego još ako ima iza sebe takvu povijest primili, onda to zaista, ne znam, mora bit valjda, ne znam, širokog srca da prime." (STR6)

83 „... jer se nekad u natječaju imaju, nazovimo to nerealna očekivanja. Da osoba bude mlada, da zna tri strana jezika, i da ima deset godina iskustva. Mislim, mi sad karikiramo, ali to je ono što poslodavci znaju navesti." (STR15)

84 „Tu je onaj dio što njima, k'o da se to ne tiče, iako izlaze za tri mjeseca na tržište rada i tu je onaj dio neinformiranosti, što kroz obrazovni sustav, što kroz društvo nekako općenito, što se tek u zadnjih par godina počelo uopće pričat o mladima i tržištu rada, do sad je bilo, evo, gotova ti škola, snađi se. Tako da, tu vidimo veliki problem, u biti u neinformiranosti oko tog prelaska na tržište rada." (STR1)

85 ,... stvarno se sad ne mogu sjetit da su oni naveli da im je nešto teško, većinom, evo, to što kažem, je mala plaća il im se ne sviđa radno vrijeme ili, ne znam, ovaj neće konobarit, ovaj ne bi radio bauštelu i tako. Oni dosta isto selektivno nekako i biraju i imaju ta nerealna očekivanja." (STR5)

86 „Dosta natječaja vam traži radno iskustvo zato jer je poslodavcima bitno da vi znate radit, e sad, vi ne možete čovjeka koji je sad izašo s fakulteta uputit na natječaj za koji se traži godina dana iskustva. Neće proć. Vi njemu možete reć da se on može javit, ne može mu niko zabranit da se javi, ali a priori znate da vjerojatno neće proć. Takvih je natječaja jako puno." (STR12) 
Stručnjaci jasno naglašavaju kontekst obrazovanja i tržišta rada kao znatan dio uzroka ulaska u NEET populaciju. Obrazovni sustav nije prilagođen potrebama suvremenog tržišta rada na koje je s druge strane teško ući tim mladima zbog njihovih obilježja. Osim toga, strukturne manjkavosti nisu uklonjene prikladnim stručnim radom i prikladnim socijalnim politikama. Vrijedi naglasiti da u vremenima krize mladi radnici trpe više različitih posljedica od starijih radnika (Quintano, Mazzocchi \& Rocca, 2018; Bruno, Marelli \& Signorelli, 2014; Caroleo et al., 2020). Uzevši u obzir da je Hrvatska bila suočena sa znatnim posljedicama u prošloj ekonomskoj krizi te uz naznake da aktualna pandemija također ostavlja ozbiljne negativne posljedice na nacionalnu ekonomiju (OECD, 2020), pitanje integracije NEET populacije na tržište rada dobiva dodatno značenje u smislu nalaženja strategija za rješavanje toga važnog društvenog pitanja.

Jedan od mogućih odgovora na ta važna pitanja bilo bi vrijedno temeljiti na upoznavanju obilježja mladih koji pripadaju NEET populaciji kako bi se dugoročne i održive strategije pravodobno i ciljano implementirale za unapređenje sustava obrazovanja, profesionalne orijentacije i tržišta rada.

Tablica 5. Obilježja položaja NEET populacije / mladib u riziku da postanu NEET

\begin{tabular}{|l|l|}
\hline TEME & \multicolumn{1}{|c|}{ POJMOVI } \\
\hline $\begin{array}{l}\text { izazovi dohvata NEET } \\
\text { populacije }\end{array}$ & $\begin{array}{l}\text { praćenje i evidentiranje NEET populacije } \\
\text { privlačenje NEET populacije prema stručnom radu }\end{array}$ \\
\hline $\begin{array}{l}\text { otežavajući čimbenici izlaska iz } \\
\text { NEET statusa - obilježja mladih }\end{array}$ & $\begin{array}{l}\text { specifične fizičke i psihičke karakteristike } \\
\text { socijalne vještine } \\
\text { informiranost } \\
\text { motivacija }\end{array}$ \\
\hline $\begin{array}{l}\text { otežavajući čimbenici izlaska iz } \\
\text { NEET statusa - obilježja okoline }\end{array}$ & $\begin{array}{l}\text { uloga roditelja } \\
\text { društvene vrijednosti }\end{array}$ \\
\hline posljedice NEET statusa & $\begin{array}{l}\text { pasivnost i besperspektivnost } \\
\text { psihičke posljedice } \\
\text { iseljavanje iz države }\end{array}$ \\
\hline
\end{tabular}

Izvor: autori.

Što se tiče specifičnih obilježja položaja mladih u NEET statusu ili njihovih rizika da uđu u taj status, stručnjaci prepoznaju neke elemente (dohvatljivost, individualni rizici, okolinski rizici i posljedice) koje mogu doprinijeti riziku da mladi postanu dio NEET populacije. 
Prvo, to je populacija koja je javnim ustanovama i stručnim službama teško dostupna, pa stručnjaci upozoravaju na izazove dohvata NEET populacije. Kada ti mladi više nisu u registru službenih evidencija (najčešće Hrvatskog zavoda za zapošljavanje), njima se gubi trag, pa stručnjaci upozoravaju na to da oni postaju "tihi i nevidljivi“ te ih je teško pratiti. ${ }^{87}$ Postoje znatni izazovi da ih se privuče i uključi u neki vid stručnog rada ${ }^{88}$ kako bi im se pružila prigoda za samostalan život.

Nadalje, stručnjaci upozoravaju na različite faktore koji otežavaju izlazak iz NEET statusa, pri čemu navode one koji se odnose na obilježja mladih - otežavajući čimbenici izlaska iz NEET statusa - obilježja mladih. Naime, neki mladi imaju intelektualne ili fizičke poteškoće, različite tipove bolesti s kojima se suočavaju te to svakako znatno otežava njihovu socijalnu i radnu integraciju. ${ }^{89} \mathrm{~S}$ druge strane, stručnjaci navode i loše obrazovanje, siromaštvo ili pripadnost romskoj populaciji kao otežavajuće faktore. ${ }^{90}$ Oni jasno naglašavaju da mnogim NEET-ovcima nedostaju socijalne vještine kako bi prezentirali vlastite potencijale ili bili uspješniji u traženju posla. ${ }^{91}$ Te meke vještine oni često ne stječu od roditelja ni u školi, a jako su važne za vlastitu promociju i uključivanje u društvo, pri čemu stručnjaci vide da mladi nisu adekvatno informirani ni o svojim pravima

87 „Druga stvar je, mislim što je taj broj, se izgubi ... To, kak bi rekla, ta kategorija i nastoji bit nevidljiva. On neće doć s bombom i tam napravit cijeli cirkus i reć dajte mi poso, ne, nego ti ga, ako želiš njega stvarno u obrazovni proces ili u bilo kakav radni, ti moraš njega za rukav loviti, tražiti i pokušavat ga u sustav, to je takva kategorija, oni ne traže pomoć, oni ne žele pomoć, oni su antiproti." (STR7)

88 „Nevoljko oni odlaze bilo gdje. Definitivno, da, definitivno bi bio bliži njima, vi morate znati da su to naša djeca koja ... Teško ih je pridobit na suradnju, znači oni, oni tu da dođu kod mene, ja na početku se obično... Hrpa odlazaka i u obitelj, i da oni tu dolaze i u školu i taj neki krug dosta treba vremena da u biti ih pridobijete na nekakvu suradnju. Pridobijete da dobijete taj odnos sa njima da oni počinju se otvarati ..." (STR3)

89 „Ne, ne nužno invaliditet, ne nužno invaliditet, nego nekako duže liječenje, recimo, mislim, dat ću ružan primjer, zloćudne bolesti i tako... On će, nažalost, bolest ne bira, jel, ali osoba će samim time što ima nekakav, ne daj bože karcinom, da će, da neće daljnje xy godina ili mjeseci moć radit. Jer neće moć." (STR12)

90 „Da, ja bi evo htio naglasiti taj dio mladih kojih, koji su naj nesuradljivi, koje je najteže pokrenuti, koje je najteže dotaknuti, dvije glavne skupine, djeca koja su u ustanovama socijalne skrbi, i djeca koja žive u ... u ... i mladi, koji žive u dugotrajnom siromaštvu." (STR4)

91 „Mladi ne znaju doć i reć imam razvijene komunikacijske vještine, ne znam, imam razvijene vještine organizacije, planiranja, slaganja prioriteta, ne znamo se prezentirat $\mathrm{u}$ tom nekakvom svjetlu, nego se više! prezentiramo ja sam taj i taj, po struci sam to i to, radila sam to i to. Tu onda mislimo da se iz toga mogu iščitat naše vještine, a ljudi koji su u firmama, pogotovo ako su međunarodne ili nešto, oni očekuju taj skills nekakav jer je vani puno bitniji skills nego tehničko znanje." (STR1) 
kao ni o mogućnostima na tržištu rada. ${ }^{92}$ Jedan je od ključnih aspekata na koji stručnjaci upozoravaju manjak motivacije NEET populacije ${ }^{93}$ za pozitivnu promjenu jer oni u veliku broju slučajeva nisu spremni surađivati s institucijama ni pokazati proaktivnost u zauzimanju za vlastito dobro. $\mathrm{S}$ druge strane, dio stručnjaka upravo iskazuje da mlade danas u jednom dijelu odlikuje i poduzetnost. ${ }^{94}$

Stručnjaci osim toga prepoznaju različite aspekte okoline koji mogu biti otežavajući čimbenici izlaska iz NEET statusa - obilježja okoline. U te čimbenike ulaze obilježja roditelja mladih, pri čemu stručnjaci procjenjuju da su u brojnim slučajevima roditeljske vještine manjkave ili roditelji zatvaraju oči pred problemima. ${ }^{95}$ Osim toga, iskustva stručnjaka pokazuju da NEET-ovci često dolaze iz niskoobrazovanih ili siromašnih obitelji, a jedan dio njih dolazi iz obitelji u kojima ne dobivaju roditeljsku potporu, ili su im roditelji u sukobu sa zakonom zbog kriminalnih radnji, ili iskazuju neki od oblika ovisničkog ponašanja. S druge strane, iskustva stručnjaka pokazuju da društvene vrijednosti promoviraju brz uspjeh i NEET populaciji iskrivljuju realnu sliku mogućnosti integracije na tržište rada i u društvo. Pritom stručnjaci upozoravaju na utjecaj društvenih mreža koje daju sliku celebrity kulture i instantnog uspjeha. Osim toga, stručnjaci uočavaju da mladi vide da mnogi ljudi u društvu uspijevaju ne s onim što znaju, već s onim koga znaju, ili upitno legalnim aktivnostima, što ih svakako demotivira da vide vrijednost u predanom radu. ${ }^{96}$

92 „Manje, manje u smislu, više imaju informacija, al manje konkretnih informacija i oni sad jako puno znaju šta sve mogu, mogu van, mogu ovdje, mogu ondje, onda ih pitaš, a okej, a kako se ide van, okej, a kako se ovdje traži posao, e to ne znam. Znači, oni znaju nekakve načelne stvari šta sve mogu, ali onda konkretno kad se uđe s njima, zato volimo raditi individualna savjetovanja." (STR1)

93 „Najviše to kako ih motivirati. To je glavni izazov da bilo što što im se nudi, čak i ta neka predavanja i radionice, da ih se potakne da se zainteresiraju za to jer oni misle da im je sve to dostupno." (STR11)

94 „Ja mislim da jesu aktivniji, ali opet se ne može poopćiti, ali u odnosu na prije, sigurno nam se javlja više mladih ljudi koji imaju nekakve poslovne ideje, ali s druge strane, nismo imali prije te potpore." (STR9)

95 „Jest da su djeca bila teška, teško odgojiva i tako dalje, sve te etikete, ali, ovaj, to su roditelji koji nisu dali djeci baš nikakve temelje i zato ja vidim roditelje kao... svakako ih treba uključiti i treba raditi sa roditeljima." (STR4)

96 „Pa zato što imate, ne znam, nekoga tko je napravio veliku pronevjeru ili nešto, suđenje godinama, otišlo u zastaru ili nije, il je dosuđeno da nema dovoljno dokaza pa se izvukao pa šeta, mislim to je društvo takvo kakvo je i... A naša djeca to vide i koju im poruku šaljemo? Da ne moraš ići u školu, da ne moraš, da možeš biti kriminalac i možeš dobro prolaziti." (STR3) 
$\mathrm{Na}$ kraju stručnjaci uočavaju različite posljedice bivanja u NEET statusu. Osim očita manjka zaposlenja koje nosi i manjak potencijalnih prihoda za život, stručnjaci vide i naglašavaju druge posljedice, pri čemu ističu da mladi nakon određena bivanja u NEET statusu tonu u pasivnost i besperspektivnost. ${ }^{97}$ Također navode da vide psihičke posljedice kod tih mladih poput razvijanja depresije i drugih mentalnih stanja koja imaju negativan utjecaj na njihovu želju za aktiviranjem..$^{98} \mathrm{Na}$ makrorazini, prema iskazima stručnjaka, brojni mladi NEET-ovci vide iseljavanje iz države kao „ruku spasa“ za svoju situaciju i sve se više prema tomu usmjeravaju. ${ }^{99}$

Brojni su individualni faktori koji prema stručnjacima otežavaju mogućnosti integracije NEET populacije. Oni su usklađeni s prepoznatim faktorima u istraživanju Eurofounda (2016), što se tiče socijalnih i fizičkih poteškoća. Osim toga, obiteljski kontekst može imati znatan utjecaj, što zajedno s navedenim kontekstualnim uvjetima može proizvesti znatne posljedice na životne i radne putanje mladih. Određena istraživanja (Gaspani, 2018) pokazuju da pripadnici NEET populacije imaju problema u stjecanju priznata socijalnog statusa i u dizajniranju vlastitih orijentacija prema budućnosti, što im otežava razvoj identiteta i vlastite pozicije u društvu.

\section{Diskusija}

Mladi koji nisu zaposleni niti su u sustavu obrazovanja i osposobljavanja (NEET populacija) posebno su ranjiva skupina u društvu jer su upravo oni izloženi rizicima trajnijeg nezapošljavanja, siromaštva, socijalne isključenosti, smanjenja motivacije za ostvarivanje obitelji i sl. (Obadić, 2017). Posljedice ekonomske krize nerijetko pogađaju nezaposlene mlade, a

97 „Ovaj, neki su u otporu, ne vide perspektivu, ne vide korist, neki imaju tako nekakve složenije poteškoće uslijed kojih dolazi do jednog, jedne pasivnosti, povlačenja, izbjegavanja obveza, provođenja većinu vremena u tom nekom virtualnom svijetu, zakazivanja na svim područjima." (STR2)

98 „Nažalost da, al onda se osjećaju neuspješnim i odbačenim, shvaćate? Jer smatraju da nisu ništa postigli u životu, nisu završili školu, nemaju nikakav posao i onda postane još veći problem. Psihijatrija, alkohol i tako dalje." (STR7)

99 „Da. Uglavnom u zadnje vrijeme svi sanjaju o velikoj Njemačkoj kao jedan oblik spasa jer uglavnom u Njemačkoj kad se zaposle ... on je otišo u Njemačku i tamo na baušteli zaradi, ne znam, tri tisuće eura, šta bi ovdje, realno, radio za možda tri tisuće kuna, tri i pol tisuće kuna. I onda im je to, to su im uglavnom sad jako veliki snovi, više njih, odlazak u Njemačku. To oni sad kao vide kao neko veliko rješenje stvari." (STR6) 
(socijalne) politike nastoje usmjeriti svoje strategije i resurse tražeći nove načine nošenja s tim socijalnim problemom i sprečavanjem radne i svake druge isključenosti mladih. Vezano uz sadašnju ekonomsku krizu koja je izazvana pandemijom COVID-19, mladi su prepoznati kao jedni od najvećih gubitnika zajedno s nezaposlenima. Osim toga, oni iskazuju osjećaj isključenosti iz društva, pa se procjenjuje da su u najvećem riziku od ulaska u depresiju jer ograničenja nastala tijekom karantene i drugih nešto blažih epidemioloških mjera uz kretanje i druženja ipak snažno utječu na njihovo psihičko zdravlje (Eurofound, 2020).

Ovim kvalitativnim istraživanjem željelo se steći uvide u iskustva i perspektive mladih u NEET statusu i stručnjaka koji s njima rade o različitim rizicima ulaska u NEET status, njegovim nepovoljnim posljedicama te perspektivi mladih u kontekstu njihova mogućeg zaposlenja.

Kada usporedimo perspektive mladih o vlastitim okolnostima i životnim uvjetima i perspektivu stručnjaka o njima, vidimo da se mnoge kategorije preklapaju, što sugerira da je prepoznat „zajednički teritorij“ ranjivosti mladih na isključenost iz društva i tržišta rada, stoga će u nastavku biti predstavljeni bitni aspekti dobivenih rezultata.

Kada je riječ o percepciji specifičnih obilježja mladih u NEET statusu, vidljivo je da su osobne karakteristike mladih poput nedostatka različitih vještina, osobito mekih, vrlo izražene. Iskustva stručnjaka koji rade s NEET populacijom, a što dijelom i mladi sami prepoznaju, govore da je riječ uglavnom o populaciji kojoj nedostaju socijalne vještine za osobnu promociju i zastupanje, što doprinosi njihovoj nezaposlenosti. Nemotiviranost i pasivnost na općoj razini još ih više udaljavaju od svijeta rada i društva. Nezaposlenost mladih, a osobito ona dugotrajna, ima ozbiljne posljedice na pojedinca, njegovo samopouzdanje (Bedeniković, 2017a) i iz te perspektive može biti trajni otklon životne i radne putanje. Mladi koji se nalaze u NEET statusu pogođeni su različitim nepovoljnim životnim okolnostima. Čimbenike koje Eurofound (2016) prepoznaje kao pojačivače rizika za ulazak u NEET populaciju, poput nepovoljnosti vezanih uz sustav obrazovanja, obiteljski dohodak, imigrantski status i zdravlje mladih, prepoznaju se i u Hrvatskoj. ${ }^{100}$ Ovo istraživanje pokazalo je da specifične karakteristike zdravstvenog statusa i invalidnost, nisko obrazovno postignuće i siromaštvo obitelji stručnjaci vide kao važne rizike mladih za njihovu nezapošljivost. Uz navedeno, podaci Eurostatova istraživanja upućuju na činjenicu da su mladi s problemima mentalnog zdravlja ili u 
ponašanju u riziku od neuspješne tranzicije iz obrazovanja na tržište rada (Rodwell et al., 2018). Tamesberger i suradnici (2014) zaključili su da su uzroci ulaska mladih u NEET status uglavnom povezani s čimbenicima kao što su spol (djevojke su češće), iskustvo ispadanja iz obrazovnog sustava i nezaposlenosti, lošije socijalne, ekonomske i stambene prilike, zatim obilježja roditelja vezana uz, primjerice, njihov obrazovni i migrantski status te utjecaj šire okoline (najčešće stigmatizacija zbog nižih obrazovnih i socijalnih ishoda).

Istraživanja pokazuju da je dječje siromaštvo bitan problem koji se može perpetuirati u daljnje životne posljedice, što je posebno istaknuto u poslijekriznom periodu (Stubbs et al., 2017; Ajduković, Dobrotić \& Matančević, 2017a; Ajduković, Matančević \& Rimac, 2017b). Mladi koji su odrasli u siromaštvu u Hrvatskoj deprivirani su u praktički svim područjima života, što dovodi do lošijih karijernih i obrazovnih ishoda (OBRIRK, 2016). Osim toga, socioekonomski status obitelji mladih, roditeljski resursi pružanja razumijevanja i potpore prepoznati su kao važni čimbenici za uspješno nošenje mladih s različitim rizicima, pa tako i s rizikom nezaposlenosti.

U tom je smislu dostupnost različitih usluga na lokalnoj i nacionalnoj razini bitna kako bi se premostilo razdoblje utjecaja rizika i za mladu osobu i za obitelj u cjelini te da bi ih se osnažilo da ne uđu u rizik socijalne isključenosti i siromaštva (Berc, Blažeka Kokorić \& Opačić, 2020). Što se tiče socijalnih usluga, nejednakosti u dostupnosti i kvaliteti primjećuje i Babić (2018). S druge strane, govoreći općenito o javnim uslugama, Koprić (2016) navodi da sustav lokalne samouprave zbog „konceptualnih, organizacijskih i praktičnih razloga nije u stanju pružati jednaku razinu usluga uz prihvatljivu cijenu i kvalitetu na svim dijelovima državnog područja“" (Koprić, 2016, str. 7). Također, recentne Preporuke Europske komisije u Hrvatskoj upozoravaju na neujednačenu kvalitetu javnih usluga (2020b, str. 6).

Grad Zagreb, područje ovog istraživanja, kao glavni grad Republike Hrvatske ima poseban status grada i županije te je znatno ekonomski razvijeniji od ostatka Hrvatske. Primjerice, po indeksu razvijenosti od 117,758 Zagreb je na prvom mjestu u Hrvatskoj. Osim što je kao lokalna jedinica razvijeniji u ekonomskom aspektu, Grad Zagreb ima i veću dostupnost različitih usluga i programa za mlade, posebice za one u nepovoljnom položaju (Grad Zagreb, 2014; Babić \& Baturina, 2019) te ima izdašno razvijenu socijalnu politiku zbog čega ga se može smatrati lokalnom socijalnom državom (Babić \& Baturina, 2019). Grad Zagreb stoga može biti 
u prilici imati i opsežnije socijalne usluge i izdatke za pojedine skupine, što može biti daljnji generator nejednakosti, ali i mogućega „socijalnog turizma“. S obzirom na spomenuto, aspekt neujednačene razvijenosti pojedinih lokalnih samouprava, a time i dostupnosti različitih usluga unutar njih, sugeriraju da je situacija i za NEET populaciju u većini ostatka države (izvan Grada Zagreba) nepovoljnija. No, kao potencijalno bitan faktor $\mathrm{u}$ tom kontekstu istraživački izvještaj o kvaliteti lokalnoga javnog upravljanja u Hrvatskoj (Hoffman et al., 2017) navodi probleme političkog i regulatornog zarobljavanja javnih institucija i resursa sa svrhom ostvarivanja partikularnih interesa pojedinaca, skupina ili mreža moći, što može utjecati i na razvoj javnih (socijalnih) usluga u različitim jedinicama lokalne samouprave. Općine i gradovi često preuzimaju aktivnu ulogu u pokretanju lokalnih inicijativa za NEET populaciju (Matković \& Karačić, 2019), i tu se može vidjeti prostor daljnjeg razvoja suradnji i novih projekata.

Posljedice NEET statusa koje se osim u siromaštvu mogu očitovati u vlastitoj obeshrabrenosti mladih dobivaju posebno značenje. Određena pasivizacija mladih prema percepciji stručnjaka ne može iznenaditi posebice u kontekstu aktualne generacije mladih koja se zbog manjka prigoda za socijalno i ekonomsko uključivanje ponegdje naziva i osujećenom (Ilišin \& Spajić Vrkaš, 2017).

Kad je u pitanju percepcija sudionika istraživanja o obrazovnom sustavu, vrijedi spomenuti da oni procjenjuju da im sustav nudi zastarjela znanja i metode rada te da zbog toga uočavaju nedostatak vlastitih praktičnih vještina i iskustava. Naglašena je nužnost sustavnijeg rada s mladima već u školama što se tiče njihova usmjeravanja i informiranja u traženju zaposlenja. Više je nego razvidno da su nužne promjene u obrazovnom sustavu $\mathrm{u}$ vidu neusklađenosti obrazovnih programa s tržištem rada i u povećanoj potrebi usmjerenosti na praksu, na što već duže vrijeme upozoravaju stručnjaci (primjerice Obadić, 2017), ali i javnost. U vezi s tim Biavaschi i suradnici (2012) u svojoj analizi zagovaraju sustave strukovnog obrazovanja i osposobljavanja koji kombiniraju radno iskustvo i obrazovanje. U tom je kontekstu 2013. godine prihvaćen Zakon o Hrvatskom kvalifikacijskom okviru, kojim se uređuje sustav kvalifikacija u Hrvatskoj (NN 2013), a posljedično tomu u akademskoj godini 2013./2014. korigirane su upisne kvote jedino u biomedicinskim znanostima na Sveučilištu u Zagrebu (Obadić, 2017). S druge strane, pokrenuta je reforma strukovnog obrazovanja $^{101}$ te bi, uz program razvoja strukovnog obrazovanja koji je pretho-

101 https://mzo.hr/hr/rubrike/aktualni-projekti 
dio (Ministarstvo znanosti i obrazovanja, 2016), mogla biti zalog prema pozitivnim promjenama u tom smjeru. Veću ulogu mogu imati i učilišta za obrazovanje odraslih u suradnji s javnim ustanovama ili organizacijama civilnog društva, no nužnim se vidi uspostava integriranog modela potpore aktivaciji NEET populacije (Matković \& Karačić, 2019).

Vrijedi istaknuti da sudionici istraživanja uočavaju da postoje neusklađenosti između očekivanja nezaposlenih mladih koji traže posao i potražnje tržišta rada te očekivanja poslodavaca. Iz tog razloga iskazuje se potreba da programi prevencije i integracije NEET populacije na tržište rada i u društvo budu usmjereni prema specifičnijim edukacijama za mlade sa svrhom učenja vještina za zapošljavanje ili za stjecanje zanimanja traženih na tržištu rada (Bežovan et al., 2019). U tom kontekstu važna je informiranost mladih o mogućnostima zapošljavanja, pri čemu vrijedi spomenuti da je tijekom 2017. i 2018. godine nastavljen rad na izgradnji kapaciteta centara za informiranje i savjetovanje o karijeri (dalje u tekstu: CISOK) kao novih oblika pružanja usluga cjeloživotnoga profesionalnog usmjeravanja osobama koje nisu prijavljene u evidenciji HZZ-a. CISOK centri prepoznati su i kao središnja mjesta za aktivnosti dohvata NEET osoba te su prilagođeni potrebama te populacije i lokalnom stanju na tržištu rada. Aktivnosti CISOK-a obuhvaćaju samopomoć, e-usluge, kratke asistirane usluge i usluge individualnih savjetovanja, a dostupne su na portalu e-Usmjeravanje, koje uključuje alate za samoprocjenu, informacije o zanimanjima, informacije o slobodnim radnim mjestima, mogućnostima za obrazovanje i drugo (Ured za karijere, 2015). U hrvatskom kontekstu cjeloživotno obrazovanje kao bitan aspekt ove teme poprima sve više pozornosti iako još imamo jako niske stope obrazovanja odraslih. ${ }^{102}$ Također, sustavno i kvalitetno provođenje građanskog odgoja i obrazovanja u školama nužno je kako bi se jačalo demokratske političke kulture i sudjelovanje mladih u donošenju odluka i životu društva, što je trenutačno zanemareno (Šalaj, 2018).

Na tržištu rada sudionici istraživanja vide manjak mogućnosti zaposlenja, ${ }^{103}$ pa se snalaze na različite načine, bilo putem različitih mjera poticanja zapošljavanja, rada na crno ili studentskih ugovora. Mladi uočavaju da za mnoge od njih nema mjesta na tržištu rada i da njihove vještine ne odgovaraju potrebama tržišta rada. Stoga se mogućnosti mladih percipiraju

102 Prema podacima Eurostata (2019b), tek je 2,9 \% odraslih osoba u Hrvatskoj u 2018. sudjelovalo u obrazovanju i osposobljavanju.

103 Rezultati jednoga recentnog istraživanja (Čepo, 2019) govore da većina mladih (69 \%) svoj položaj na tržištu rada ocjenjuje kao loš ili jako loš. 
kao limitirane. U hrvatskom kontekstu koji bilježi najveće stope prekarnog rada u Europi mladima je još teže napraviti tranziciju iz obrazovanja u stabilno zaposlenje. ${ }^{104}$

Mjere aktivne politike zapošljavanja, prema uvidima stručnjaka, pokazuju mješovite rezultate kao potencijal integracije. ${ }^{105}$ Slični nalazi mogu se vidjeti i iz evaluacije tih mjera (Bejaković et al., 2016). Jedan od razloga sužena prostora za zapošljavanje mladih može se vidjeti i u neprovođenju strukturnih promjena (Bejaković \& Mrnjavac, 2016). Ostaje još vidjeti koliko će u sljedećem razdoblju Garancija za mlade i sredstva koja stoje na raspolaganju ostvariti uspjeha $u$ integraciji NEET populacije. Trenutačni podaci govore da Hrvatska ima iznadprosječnu pokrivenost mladih u tzv. NEET statusu mjerama Garancije za mlade (MDOMSP, 2020). ${ }^{106}$ No neke od posljednjih procjena Europske komisije (Europska komisija, 2020c) govore o potrebi unapređenja suradnje HZZ-a i obrazovnih institucija, o integriranju Garancije za mlade i cjeloživotnog obrazovanja te prilagođavanju aktivnih politika tržišta rada. Iskustva skupina osoba u NEET statusu koje se žele zaposliti govore da se rijetko koriste postojećim mjerama aktivacije jer nemaju informacije o programima ili uslugama, ponuđene usluge nisu im dostupne iz različitih razloga ili ih ne vide kao korisne u traženju posla (Matković \& Karačić, 2019). ${ }^{107}$

Opće stanje u državi i društvu i mladi i stručnjaci koji su bili sudionici ovog istraživanja procjenjuju vrlo nepovoljnim. Nisu imuni na nezadovoljstvo u sustavima u kojima sudjeluju te vide brojne negativne konotacije tih sustava i šire okoline poput nepotizma i korupcije. Osim toga, stručnjaci ne vide da su mladi cijenjeni ili prepoznati kao društveni potencijal i prioritet, a dodatno demotivirajućima vide se vrijednosti koje prevladavaju u društvu, a koje ne promiču meritokraciju, što i mladi primjećuju (to dijelom sugerira i istraživanje Gvozdanović, 2014). Može se reći da postoji perspektiva generacijskog problema nebrige društva o mladima (Kovačić

104 https://ec.europa.eu/eurostat/web/products-eurostat-news/-/DDN-20180209-1

105 Doseg je aktivnih politika zapošljavanja neujednačen. No, primjerice, 2011. 2016. obuhvaćenost mladih nezaposlenih porasla je sa $17 \%$ na $38 \%$, pri čemu su najveći doprinos dale mjere stručnog osposobljavanja (Matković \& Karačić, 2019).

106 No ključni izazov ostaju mlade NEET osobe koje se ne prijavljuju u evidenciju HZZ-a radi potpore pri zapošljavanju. Naime, oni ne ulaze u Garanciju za mlade (MDOMSP, 2020). nije.

107 Istraživanje je provođeno u kontekstu Međimurske i Vukovarsko-srijemske župa- 
\& Gvozdanović, 2017) ${ }^{108}$ te mladi zbog takve percepcije nerijetko gledaju jednim okom preko granice (što ističe i istraživanje Potočnik \& Adamović, 2018). U tome ih potiče kombinacija privlačnih ekonomskih i društvenih čimbenika, pri čemu ekonomski dominiraju. ${ }^{109}$

To je jedan dio zapreka i okolnosti s kojima se mladi susreću u rješavanju pitanja vlastitog zapošljavanja koje čine njihov život izazovnim. Iako je istraživanje provedeno u ograničenom kontekstu, za neke zapreke možemo reći da su sustavne prirode i imaju utjecaja i u drugim dijelovima Hrvatske. Može se također reći da sudionici ovog istraživanja borave u iznadprosječno razvijenoj lokalnoj zajednici, pa se može pretpostaviti da drugi aspekti vezani za nedostatak materijalnih resursa i društvene infrastrukture čine situaciju u drugim dijelovima Hrvatske još poraznijom. Dostupni podaci o prisutnosti razlika u resursima lokalnih zajednica u Hrvatskoj govore da je dostupnost većine prava i usluga znatno niža u općinama s nižim indeksom razvijenosti i u općinama udaljenijima od središta županije (Berc, Blažeka Kokorić \& Opačić, 2020, Ministarstvo regionalnog razvoja i fondova Europske unije, 2020). Tako, primjerice, mjesta s višim indeksom razvijenosti imaju osiguran veći broj različitih socijalnih prava i usluga među kojima su prava na materijalnu potporu u obrazovanju te veći broj usluga u odgoju i obrazovanju. Osim toga, u manjim općinama koje su udaljenije od središta županije stanovništvo je manje uključeno u procjenu potreba za novim uslugama, kao što su to usluge vezane uz potporu u obrazovanju mladih, pa su time manje sredine i po toj osnovi u nejednakom položaju (Berc, Blažeka Kokorić \& Opačić, 2020).

Dakle, očekivano, ruralne zajednice funkcioniraju u višestruko većim razvojnim nepovoljnostima, osobito vezano uz otežanu dostupnost obrazovnih ustanova zbog slabe prometne povezanosti ruralnih sredina s obrazovnim i poslovnim središtima. Stoga je NEET populacija ruralnih zajednica s velikim razlogom u fokusu praćenja COST-a jer je prema dostupnim podacima ta populacija zastupljenija za $15 \%$ u ruralnim nego u urbanim sredinama, i to osobito u južnoj i istočnoj Europi te je u pojačanom riziku od siromaštva i socijalne isključenosti (COST, 2021).

Kao što je navedeno, ovo istraživanje provedeno je na području Grada Zagreba, što je razvijenija jedinica lokalne samouprave od ostalih dijelo-

108 Primjerice, Nacionalni program za mlade donesen je za razdoblje do 2017. godine, a početkom 2020. godine tek imamo Nacrt programa za razdoblje 2020. - 2024.

109 http://ideje.hr/iseljavanje-visokoobrazovanih-prihodi-ali-i-korupcija-i-opci-osjecaj-netrpeljivosti-u-drustvu/ 
va Hrvatske po dostupnosti programa i usluga savjetovanja pri zaposlenju, po mogućnostima zaposlenja te po specifičnoj ulozi Hrvatskog zavoda za zapošljavanje, pa se dobiveni rezultati ne mogu primijeniti na cijelu Hrvatsku. Navedeno može predstavljati ograničenje istraživanja uz činjenicu da je u njemu odabran kvalitativni pristup prikupljanja ${ }^{110}$ i obrade podataka, što također rezultira ograničenjima u generalizaciji istraživačkih rezultata. Uzorak istraživanja koji se odnosi na NEET populaciju definiran je prema načelu dobrovoljnosti i dostupnosti, pri čemu se mladima pristupilo kroz ponudu različitih projektnih aktivnosti kako bi ih se motiviralo na sudjelovanje u istraživanju, što je ograničilo obuhvat ukupne heterogenosti te populacije. Međutim, unatoč spoznajama da je riječ o izrazito heterogenoj skupini koju Eurofound (2016) svrstava u sedam potkategorija s različitom razinom ranjivosti i izloženosti socijalnoj isključenosti (od gotovo minimalne do izrazite), ovaj uzorak promatran je kao jedinstvena skupina jer se željelo početi od osobnih iskustava i doživljaja učinkovitosti obrazovanja za njihovo zapošljavanje te zadovoljstva kvalitetom usluge koje su dobili od HZZ-a u traženju posla. Također, stručnjaci koji su činili drugi dio uzorka imaju zbog svojih karakteristika širi pogled na NEET populaciju.

Smatramo da dobiveni rezultati svakako mogu dati smjernice za daljnja istraživanja te zahtjevne tematike koja se tiče mladih u Hrvatskoj. Riječ je o jednom od pionirskih kvalitativnih istraživanja u ovome tematskom području koje je imalo cilj steći dublji uvid u osobna iskustva statusa u kojem živi teško dostupna NEET populacija (jer se ne vodi njihova sustavna evidencija) te koje nudi znatan doprinos iz perspektive stručnjaka koji s njima rade o položaju tih mladih u društvu i njihovim izgledima na tržištu rada. Stoga je ovom istraživanju svrha otvoriti vrata daljnjim istraživanjima, razmatranjima mogućih strategija pristupa i praćenja te populacije na razini lokalne samouprave te pridonijeti široj znanstvenoj i stručnoj diskusiji o bitnome socijalnom problemu koji ima velik utjecaj na sadašnje, ali i buduće pokazatelje socijalne i ekonomske slike našeg društva.

\section{Umjesto zaključka - kako naprijed?}

Nemogućnost pronalaska posla velik je problem za mnoge mlade u Hrvatskoj. Pripadnici NEET populacije iz ovog uzorka za svoje nezaposlenje

110 Kao i u većini kvalitativnih istraživanja, iako su postavljeni kriteriji za odabir ispitanika, uzorak nije sasvim reprezentativan te održava dijelom i pristranost prema ispitanicima koji su željeli sudjelovati u istraživanju. 
smatraju najviše odgovornim stanje u državi, okolnosti povezane s tržištem rada i načinom zapošljavanja te u tome vide bitnom ulogu Hrvatskog zavoda za zapošljavanje, a zatim i neka ograničenja povezana sa stečenim zanimanjem i neka individualna obilježja. Iskustva mladih vezana uz sudjelovanje u sustavu obrazovanja, koje je ključno za njihovo zaposlenje, uglavnom su negativna i mladi imaju mnoge zamjerke i na sam sustav i na izvedbu programa, dok je manji dio mladih iskazao zadovoljstvo obrazovanjem. Što se tiče njihova mišljenja o mogućnosti pronalaska posla u Hrvatskoj, mladi imaju dvojaka razmišljanja, i pozitivna i negativna, ali su ponovno istaknuli važnost odabira zanimanja, no i primjedbu za zapošljavanje preko veze. S druge strane, promatrajući percepciju stručnjaka koji su sudjelovali u ovom istraživanju, očito je da se i oni u velikom dijelu slažu s percepcijom mladih jer također kao glavne čimbenike koji su povezani s NEET statusom ističu nedostatke obrazovanja i obrazovnog sustava te tržišta rada, a u manjoj mjeri informiranost, očekivanja i nedostatak iskustva mladih. Za razliku od mladih koji imaju očekivanja od HZZ-a te očekuju pri traženju posla pomoć i potporu okoline, stručnjaci vide da probleme s NEET populacijom treba rješavati na višoj razini i sustavno, a za to je potrebna evidencija mladih u riziku, praćenje i kontinuiran rad s njima zahvaćajući najvažnije individualne čimbenike mladih u riziku i čimbenike okoline da ne bi došlo do posljedica na svim razinama (koje i sami stručnjaci prepoznaju i navode).

Rezultati koje smo dobili ovim kvalitativnim istraživanjem potvrđuju teorijska polazišta (ekološke teorije i teorije akumulacije nepovoljnosti) od kojih smo počeli. Percepcija mladih kao i percepcija stručnjaka jasno pokazuju da i jedni i drugi uviđaju čimbenike na različitim razinama i u različitim sustavima društva kao odgovorne za rizik nezaposlenosti, s naglaskom na okolinske čimbenike, odnosno izvanjske faktore kao najodgovornije, ali i najpozvanije za prevenciju i sprečavanje ulaska u NEET položaj. Također, kod obiju skupina sudionika vidljiva je svijest o dugoročnom riziku, odnosno riziku učinka akumulacije nepovoljnosti s naglaskom na gubljenje vjere u pronalazak posla i postizanje dobra društvenog položaja kod mladih kao i svjesnost ozbiljnih posljedica bivanja u NEET statusu iz perspektive stručnjaka.

Takvi rezultati daju naslutiti da je iznimno važno da država i društvo u Hrvatskoj promijene politiku obrazovanja i zapošljavanja mladih. Konkretno, da se vodi računa o potrebama na tržištu rada koje trebaju dobiti adekvatan odgovor kroz obrazovne programe i realne upisne kvote, da se unaprijedi uloga Hrvatskog zavoda za zapošljavanje, da se unaprijedi obrazovni sustav koji treba više približiti praksi te da se mladima osiguraju veća potpora i pomoć u vezi s odabirom zanimanja i u traženju posla. 
Europska komisija (2018a) prepoznaje određene dobre prakse u aktivaciji ranjivih mladih koji uključuju orijentaciju i profiliranje kao i kombinaciju savjetovanja, mentorstva i vođenja stručnjaka, što je naglasila i perspektiva ovog istraživanja. Ključnim drže holistički pristup orijentiran prema osobi te razvoj višedioničkih partnerstava. Unapređenje suradnje i kapaciteta potrebnih za praćenja osoba u NEET status kao potrebu pokazuje i analiza Tomić, Botrić i Žilić (2018) u hrvatskom kontekstu. Osim toga, naglašava se i važnost prevencije, sustava ranog upozorenja i intervencije. U kontekstu EU-a bitnim se vide široka partnerstva institucija u praćenju mladih u riziku, posebno u vidu razvoja servisa praćenja koji će kontaktirati s mladima prije ispadanja/nezaposlenosti (Europska komisija, 2018b). No mapiranje i praćenje NEET populacije ostaju izazovne aktivnosti i u kontekstu EU-a (ICF, 2018).

U posljednjih nekoliko godina sve se više generalno govori o otuđenju mladih, generaciji koja je izgubljena, a dinamizira se iseljavanje mladih iz Hrvatske. S druge strane, postoje socijalni rizici vezani za specifičan dio mladih, NEET populaciju za koju je ovaj rad malen korak u nužno potrebno prepoznavanje i osvještavanje njihove problematike. U ovom istraživanju postoji procjena sudionika istraživanja da je riječ o kompleksnom ${ }^{111} \mathrm{i}$ sustavnom problemu koji je važno rješavati na razini državnih institucija i osnaživanju lokalnih resursa za pružanje konstruktivne i višerazinske potpore mladima u NEET statusu i njihovim obiteljima. Stoga stavljanje mladih u fokus zahtijeva znatno više koordinacije različitih ministarstava, lokalnih zajednica i stručnjaka.

Prvi korak prema tom smjeru bila bi djelomična reorijentacija socijalne politike u Hrvatskoj. Nju odražava dualizam između onih koji imaju prava (zaposleni i umirovljenici) i onih koji su na rubu bez znatne potpore poput nezaposlenih i socijalno isključenih (Bežovan, 2019). U tom aspektu nužna je reorijentacija prema socijalnim ulaganjima od predškolskog odgoja i obrazovanja do integracije na tržište rada i cjeloživotno obrazovanje. No to bi zahtijevalo da se napokon mlade postavi u središte političke i društvene sfere. I u vidu drugih gorućih problema poput demografskog sloma $\mathrm{i}$ iseljavanja nužno je pomlađivanje retorike i prakse adekvatno praćeno i u državnom proračunu. Potreban je napredak u sve tri komponente za rješavanje pitanja nezaposlenosti i podzaposlenosti mladih koje prepoznaju Hughes \& Borbély-Pecze (2012), a to su prevencija, vraćanje i reintegra-

111 Slično, primjerice, za jedan dio NEET populacije u hrvatskom kontekstu, one koji ispadaju iz sustava obrazovanja, recentno istraživanje navodi da su heterogena populacija i naglašava kompleksnost fenomena (Ogresta et al., 2020). 
cija. Tu se tek dijelom uočava usmjerenje novoga nacionalnog programa za mlade (MDOMSP, 2020) koji prema NEET populaciji adresira jednu mjeru, navodeći i potrebu za inovacijama. ${ }^{12}$

Jedinice lokalne samouprave mogu također učiniti pomake većom suradnjom s državnim institucijama, usmjeravanjem lokalnih socijalnih politika mladima te otvaranjem prostora većem djelovanju samih mladih za mlade (primjerice savjetima za mlade ili financiranjem udruga mladih koje su bliske njihovim perspektivama).

NEET populacija definirana je kao jedan od prioriteta razvoja urbane aglomeracije Zagreba (Grad Zagreb, 2017) mehanizmima integriranoga teritorijalnog ulaganja. To jednim dijelom sugerira da se „uperilo“ svjetlo prema tom problemu. No, naravno, taj tip strategija kao i primjerice Garancija za mlade financirana sredstvima EU-a tek su jedan element u mogućem mozaiku rješenja. Problem je sustavne prirode. Ranjivost obitelji i odrastanje u siromaštvu, zastarjeli obrazovani sustav i neusklađenost s tržištem rada kao i tržište rada koje u vremenu krize i nakon krize nije bilo toliko otvoreno mladima neke su od izraženijih zadatosti koje čine rizik za postajanje dijelom NEET populacije.

U Hrvatskoj se tek u posljednje vrijeme javljaju naznake programa rada usmjerenih NEET populaciji, pa tako i na mladima "ispalima“ iz sustava obrazovanja, a koje uglavnom provode neke organizacije civilnog društva. Nameće se potreba bolje koordinacije i veće sustavnosti rada, posebice u hrvatskom kontekstu u kojem su usluge povezane sa socijalnim uključivanjem i uključivanjem na tržište rada još relativno nerazvijene. Primjerice, to mogu biti prostori aktivnijeg razvoja kombinirane socijalne politike (Matančević, 2014) ili socijalnog poduzetništva (Baturina, 2018), posebno na lokalnoj razini. Za to je moguće koristiti se sredstvima različitih fondova Europske unije (primjerice Europski socijalni fond i budući Europski socijalni fond plus) ${ }^{113}$, no njihovo programiranje i priljev trebaju biti planirani i pouzdani. ${ }^{114}$ Ekosustav socijalnih inovacija (Baturina, 2019)

112 Osim toga, ima bliske ciljeve kao što je povećati participaciju mladih na tržištu rada, posebno mladih koji su stekli nižu razinu obrazovanja te osnažiti mlade za poduzetništvo i samozapošljavanje.

113 Postoje i važne inicijative EU-a usmjerene u to područje poput Mladi u pokretu i Program za nove vještine i radna mjesta.

114 Kontinuitet rada remeti logika projektnog financiranja projekata i programa sredstvima iz Europskih fondova koja pokazuje brojne manjkavosti (Baturina, 2016). Prema nekim izvorima do te mjere da se naziva "državnim udarom na civilno društvo" (GONG, 2020). 
trebalo bi dodatno osnažiti kako bi se eksperimentiralo s novim načinima uključivanja i oblika učenja i stjecanja vještina mladih osoba da bi se pravodobno prevenirao njihov ulazak u NEET status.

\section{Popis literature}

Ajduković, M., Dobrotić, I., \& Matančević, J. (2017a). Mogućnosti unapređenja socijalne politike u smanjivanju siromaštva djece: perspektiva ključnih dionika. Ljetopis socijalnog rada, 24(2), 309-356, https://doi.org/10.3935/ljsr. v24i2.187.

Ajduković, M., Matančević, J., \& Rimac, I. (2017b). Siromaštvo djece iz perspektive stručnjaka: učinci i mogućnosti djelovanja. Ljetopis socijalnog rada, 24(2), 277-308, https://doi.org/10.3935/ljsr.v24i2.182.

Babić, Z. (2018). Decentralizacija socijalne skrbi i socijalne nejednakosti: slučaj Hrvatske. Revija za socijalnu politiku, 25(1), 25-48, https://doi.org/10.3935/ rsp.v25i1.1458.

Babić, Z, \& Baturina, D. (2019). Social plan of the city of Zagreb 2014-2020: "What Is Planned and what sas Been achieved?" Preparatory study for the social policy, jobs \& growth. Croatian Science meet regions event, held in Zagreb, Croatia 17. 10. 2019. Brussels, Belgium: European Commission Joint Research Centre.

Baturina, D. (2016.) Utjecaj trećeg sektora na socio-ekonomski razvoj Republike Hrvatske (doktorska disertacija). Zagreb, Hrvatska: Pravni fakultet.

Baturina, D. (2018). First strategy for the development of social entrepreneurship in the Republic of Croatia and potentials for the development of the sector. Croatian and Comparative Public Administration - posebni prilog uz br. 2/2018, 11-39.

Baturina, D. (2019). The struggles of shaping social innovation environment in Croatia. Annales-Anali za Istarske in Mediteranske Studije- Series Historia et Sociologia, 29(2), 323-334.

Bedeniković, I. (2017a). (Ne)zaposlenost mladih i NEET populacija u Hrvatskoj. Mali Levijatan: studentski časopis za politološke teme, 4(1), 75-90.

Bedeniković, I. (2017b). POLO Analitički osvrt NEET skupina - izazovi u Hrvatskoj, Poljskoj i Sloveniji. Dostupno na https://polocro28.irmo.hr/wp-content/ uploads/2017/02/POLO_10.-osvrt_final-I.B..pdf.

Bejaković, P., \& Mrnjavac, Ž. (2016). Nezaposlenost mladih i mjere za njezino ublažavanje u Hrvatskoj. Političke analize, 7(27), 32-38, https://doi. org/10.3935/rsp.v23i2.1361.

Bejaković, P., Dedić, D., Desović, P., Ivišić, J., Mikić, I., Penezić, L., \& Šeparović, M. (2016). Vanjska evaluacija mjera aktivne politike tržišta rada 2010. - 2013. Zagreb, Hrvatska: Hrvatski zavod za zapošljavanje. Dostupno na https:// www.hzz.hr/UserDocsImages/HZZ_i_Ipsos_Vanjska-evaluacija-mjera-aktivne-politike-trzista-rada_2010.pdf. 
Berc, G., Blažeka Kokorić, S., \& Opačić, A. (2020). Dostupnost socijalnih prava i usluga za obitelji u općinama u ruralnim područjima Hrvatske. Revija za socijalnu politiku, 27(2), 113-135, https://doi.org/10.3935/rsp.v1i3.583.

Berc, G., Bežovan, G., \& Majdak, M. (2015). Perspektiva stručnih suradnika o ispadanju učenika iz srednjih škola kao novom socijalnom problemu. Revija za socijalnu politiku, 24(1), 1-31, https://doi.org/10.3935/rsp.v22i1.1162.

Bežovan, G., Berc, G., Majdak, M., Baturina, D., \& Rozman, S. (2019). Reaktivacija $i$ integracija marginaliziranib mladih - NEET na tržište rada - RIM. Zagreb, Hrvatska: CERANEO.

Bežovan, G. (2019). Hrvatska socijalna politika u vremenu globalizacije i europeizacije. U G. Bežovan, V. Puljiz, Z. Šućur, Z. Babić, I. Dobrotić, T. Matković, \& S. Zrinščak (ur.), Socijalna politika Hrvatske II. izdanje (str. 59-108). Zagreb, Hrvatska: Pravni fakultet.

Biavaschi, C., Eichhorst, W., Giulietti, C., Kendzia, M. J., Muravyev, A., Pieters, J., Rodríguez-Planas, N., Schmidl, R., \& K. F. Zimmermann (2012). Youth unemployment and vocational training, IZA Discussion paper No. 6890. Bonn, Germany: Institute for the Study of Labor.

Bruno, G. S., Marelli, E., \& Signorelli, M. (2014). The rise of NEET and youth unemployment in EU regions after the crisis. Comparative Economic Studies, 56(4), 592-615, https://doi.org/10.1057/ces.2014.27.

Caroleo, F. E., Rocca, A., Mazzocchi, P., \& Quintano, S. (2020). Being NEET in Europe before and after the economic crisis: An analysis of the micro and macro determinants. Social Indicators Research, 149, 991-1024, https://doi. org/10.1007/s11205-020-02270-6.

CERANEO (2014). Ulaganjem u gradane za jači $i$ otporniji grad. Socijalna slika Grada Zagreba 2013. Zagreb, Hrvatska: CERANEO.

COST (2021). Tackling Youth Rural NEETs social and economic exclusion. Dostupno na https://www.cost.eu/news/rural-neets/.

Čepo, D. (2019). Odredište EU: budućnost mladib u Hrvatskoj. Zagreb, Hrvatska: Centar za demokraciju i pravo Miko Tripalo.

Eurofound (2016). Exploring the diversity of NEETs. Luxembourg: Publications Office of the European Union.

Eurofound (2020). Living, working and COVID-19. COVID-19 series, Luxembourg: Publications Office of the European Union. Dostupno na https:// www.eurofound.europa.eu/publications/report/2020/living-working-and-covid-19, https://doi.org/10.1101/2020.04.13.20064162.

Eurostat (2019a). 2.3\% of EU employees have a precarious job. Dostupno na https:// ec.europa.eu/eurostat/web/products-eurostat-news/-/DDN-20180209-1.

Eurostat (2019b). Adults participation in lifelong learning. Dostupno na https:// ec.europa.eu/eurostat/web/products-eurostat-news/-/DDN-20190517-1.

Eurostat (2020). Young people neither in employment nor in education and training by sex, age and degree of urbanisation (NEET rates). Dostupno na https://appsso. eurostat.ec.europa.eu/nui/show.do?dataset=edat_lfse_29\&lang=en. 
Europska komisija (2018.a). Activation measures for young people in vulnerable situations. Experience from the ground. Brussels, Belgium.

Europska komisija (2018). Effective outreach to NEETs. Experience from the ground. Luxembourg: Publications Office of the European Union.

Europska komisija (2020a). Employment, social affairs \& inclusion. Dostupno na https://ec.europa.eu/social/main.jsp?catId=1036\&langId=en.

Europska komisija (2020b). Preporuka za Preporuku Vijeća o nacionalnom programu reformi Hrvatske 2020. i dostavljanju mišljenja Vijeća o programu konvergencije Hrvatske za 2020. Brisel, Belgija, https://doi.org/10.3935/rsp.v8i1.230.

Europska komisija (2020c). Youth guarantee country by country-Croatia. Bruxelles, Belgium.

Gaspani, F. (2018). Young-adults NEET in Italy: Orientations and strategies toward the future. International Journal of Sociology and Social Policy, 38(1/2), 150-164, https://doi.org/10.1108/ijssp-04-2017-0038.

Grad Zagreb (2014). Socijalni plan Grada Zagreba 2014. - 2020. Zagreb, Hrvatska.

Grad Zagreb (2017). Strategija razvoja Urbane aglomeracije Zagreb za razdoblje do 2020. godine. Zagreb, Hrvatska.

GONG (2020). Državni udari na civilno društvo potpomognuti EU fondovima. Zagreb, Hrvatska: GONG.

Gvozdanović, A. (2014). Politički utjecaj i vrijednosti kao odrednice političkog povjerenja mladih u Hrvatskoj. Revija za sociologiju, 44(1), 5-30, https://doi. org/10.5613/rzs.44.1.1.

Hoffman, D., Miošić-Lisjak, N., Prkut, D., Stubbs, P., Šalaj, B., Zelić, D., \& Zrinščak, S. (2017). Naša zarobljena mista. Istraživački izvještaj studija kvalitete lokalnog javnog upravljanja u Hrvatskoj. Zagreb, Hrvatska: Gong.

Hughes, D., \& Borbély-Pecze, T. B. (2012). Youth Unemployment:A Crisis in Our Midst. ELGPN Concept Note No.2. Jyvaskyla, Finland: ELGPN.

Hsieh, H., \& Shannon, S. E. (2005). Three approaches to qualitative content analysis. Qualitative bealth research, 15(9), 1277-1288, https://doi. org/10.1177/1049732305276687.

ICF (2018.) Tracking and mapping young people not in education, employment or training (NEETs). Bruxelles, Belgium: European Commission.

Ilišin, V., \& Spajić Vrkaš, V. (2017). Uvod: konceptualni okvir istraživanja. U V. Ilišin \& V. Spajić Vrkaš (ur.), Generacija osujećenib: mladi u Hrvatskoj na početku 21. stoljeća (str. 11-30). Zagreb, Hrvatska: Institut za društvena istraživanja u Zagrebu.

Koprić, I. (2016). Reforma javne uprave u Hrvatskoj: ni bolni rezovi ni postupne promjene - nužna je nova upravna paradigma. Političke analize, 7(26), 3-12.

Kovačić, M., \& Gvozdanović, A. (2017). Poznavanje generacijskih problema i potreba kao temelj kvalitetne politike za mlade u Hrvatskoj. U V. Ilišin \& V. Spajić Vrkaš (ur.), Generacija osujećenib: mladi u Hrvatskoj na početku 21. 
stoljeća (str. 261-291). Zagreb, Hrvatska: Institut za društvena istraživanja u Zagrebu.

Matančević, J. (2014). Obilježja modela kombinirane socijalne politike u pružanju socijalnib usluga u Hrvatskoj (doktorska disertacija). Zagreb, Hrvatska: Pravni fakultet.

Matković, A., \& Karačić, D. (2019). Izvješće o provedenoj analizi i preporukama za razvoj aktivnosti s posebnim osjetlivim skupinama osoba u NEET statusu. Zagreb, Hrvatska: Ministarstvo rada i mirovinskog sustava.

Ministarstvo rada i mirovinskoga sustava (2020). Plan implementacije garancije za mlade za razdoblje od 2019. do 2020. godine. Dostupno na http://www.gzm. hr/wp-content/uploads/2014/11/Plan-implementacije-Garancije-za-mlade-zarazdoblje-od-2019.-do-2020.-godine.pdf.

Ministarstvo regionalnog razvoja i fondova Europske unije (2020). Vrijednosti indeksa razvijenosti i pokazatelja za izračun indeksa razvijenosti 2018. Dostupno na https://razvoj.gov.hr/o-ministarstvu/djelokrug-1939/regionalni-razvoj/indeks-razvijenosti/vrijednosti-indeksa-razvijenosti-i-pokazatelja-za-izracun-indeksa-razvijenosti-2018/3740.

Ministarstvo znanosti i obrazovanja (2016) Program razvoja sustava strukovnog obrazovanja i osposobljavanja (2016. - 2020.). Zagreb: Ministarstvo znanosti i obrazovanja.

Nestić, D., \& Tomić, I. (2018). Jobless population and employment flows in recession. Journal of Balkan and Near Eastern Studies, 20(3), 273-292, https://doi. org/10.1080/19448953.2018.1385271.

Obadić, A. (2017). Nezaposlenost mladih i usklađenost obrazovnog sustava s potrebama tržišta rada. Ekonomska misao i praksa, (1), 129-150.

OBRIRK (2016). Obrazovni ishodi $i$ radne karijere mladib odraslib u siromaštvu: Izvještaj o rezultatima istraživanja. Dostupno na https://www.pravo.unizg.hr/_ download/repository/OBRIRK_Rezultati_istrazivanja.pdf.

OECD (2019). Youth not in employment, education or training (NEET). Dostupno na https://data.oecd.org/youthinac/youth-not-in-employment-education-ortraining-neet.htm.

OECD (2020). The Covid-19 crisis in Croatia. Paris. OECD.

Ogresta, J., Rezo, I., Kožljan, P., Pare, M. H., \& Ajduković, M. (2020). Why do we drop out? Typology of dropping out of high school. Youth \& society, 52, 1-21, https://doi.org/10.1177/0044118x20918435.

Operativni program-učinkoviti ljudski potencijali 2014. - 2020 (2014). Dostupno na http://www.esf.hr/wordpress/wp-content/uploads/2015/09/OPULJPhr-20150709.pdf.

Quintano, C., Mazzocchi, P., \& Rocca, A. (2018). The determinants of Italian NEETs and the effects of the economic crisis. Genus, 74(1), 5, 1-24, https:// doi.org/10.1186/s41118-018-0031-0.

Ritchie, J., \& Spencer, L. (1994) Qualitative Data Analysis for Applied Policy Research. U A. Bryman \& B. Burgess (Eds.) Analyzing Qualitative Dana (str. 
173-194). London, UK: Routledge, https://doi.org/10.4324/9780203413081_ chapter_9.

Rodwell, L., Romaniuk, H., Nilsen, W. Carlin, J. B., Lee, K. J., \& Patton, G. C. (2018). Adolescent mental health and behavioural predictors of being NEET: A prospective study of young adults not in employment, education, or training. Psychol Med, 48(5), 861-871, https://doi.org/10.1017/s0033291717002434.

Samson, R., \& Laub, J. H. (1992). Crime and deviance in the life course. Annual Review of Sociology, 18, 63-84.

Shaw, C. R., \& McKay, H. (2002) The social disorganization theory. CSISS Classics. Dostupno na https://escholarship.org/uc/item/47j411pr.

Stubbs, P., Ledić, M, Rubil, I., \& Zrinščak, S. (2017). Dječje siromaštvo i strategije nošenja sa siromaštvom kućanstava u Hrvatskoj. Zagreb, Hrvatska: Ekonomski institut Zagreb i Zaklada Adris, https://doi.org/10.15179/pkiep.26.2.2.

Šalaj, B. (2018). Zagreb: U očekivanju Godota? Politika, demokracija i građanski odgoj i obrazovanje u Hrvatskoj. Zagreb. Hrvatska: Good Inicijativa, GONG.

Tamesberger, D., Bacher, J., \& Leitgb, H. (2014). Individual and structural causes of neet - a case study of Austria. Dostupno na https://www.researchgate. net/publication/268086049_Individual_and_Structural_Causes_of_Neet__a_Case_Study_of_Austria/link/583bea3a08aef00f3bfe75d9/download.

Tomić, I., Botrić, V., \& Žilić, I. (2018). Analiza stanja i preporuke za razvoj dalinjih aktivnosti za osobe u NEET statusu (projektna studija). Zagreb, Hrvatska: Ministarstvo rada i mirovinskoga sustava.

Ured za karijere (2015). Strategija cjeloživotnog profesionalnog usmieravanja i razvoja karijere u Republici Hrvatskoj 2016. - 2020. Dostupno na http://www.ssc.uniri. hr/files/Ured_za_karijere/Strategija.pdf.

Potočnik, D., \& Adamović, M. (2018). Iskustvo migracije i planirani odlasci mladih iz Hrvatske. Zagreb, Hrvatska: Friedrich Ebert Stiftung. 


\section{DANCING ON THE EDGE: CIRCUMSTANCES AND EXPERIENCES OF YOUNG NEETS IN THE CITY OF ZAGREB}

\section{Summary}

The NEET population encompasses young people who are not involved in education, retraining or the labour market. The aim of this research was to gain insight into the experiences that members of the NEET population and professionals who work with them have had regarding the risks that lead young people to NEET status, and regarding their employment prospects. The participants were 15 experts and 25 young NEETs. Focus groups and semi-structured interviews were conducted with the purpose of data collecting. Data were analysed by the mix method. The main results have shown that young people see the reasons of their unemployment in their educational and professional qualifications that are not compatible with the labour market. They have also reported on insufficient support of public institutions they experienced while looking for work. Experts have recognized an incompatibility of the educational system and the labour market and this situation has been bighlighted as a significant risk factor for young people entering the NEET status. They have also reported on insufficient institutional evidence and systematic recording of the NEET population at the national and local levels, as well as on difficulties in monitoring the NEET population. Experts have marked leaving the NEET status and the consequences of this status as a challenging effort for both young people and the society.

Keywords: education, employment, labour market, the City of Zagreb, NEET population, experts, public institutions 